\title{
Cobalt(II) liquid metal salts for high current density electrodeposition of cobalt
}

Jeroen Sniekers, ${ }^{a}$ Pieter Geysens, ${ }^{a}$ Tom Vander Hoogerstraete, ${ }^{a}$ Luc Van Meervelt, ${ }^{a}$ Jan Fransaer ${ }^{b}$ and Koen Binnemans*,a

${ }^{a}$ KU Leuven, Department of Chemistry, Celestijnenlaan 200F - P.O. Box 2404, B-3001 Heverlee, Belgium;

${ }^{b}$ KU Leuven, Department of Metallurgy and Materials Engineering, Kasteelpark Arenberg 44 - P.O. Box 2450, B-3001 Heverlee, Belgium.

*Corresponding author. E-mail: Koen.Binnemans@kuleuven.be

J. Sniekers, P. Geysens, T. Vander Hoogerstraete, L. Van Meervelt, J. Fransaer, K. Binnemans Dalton Transactions 47, 4975-4986 (2018).

DOI: $10.1039 /$ C8DT00283E 


\begin{abstract}
Cobalt(II)-containing ionic liquids were synthesized using $N, N$-dimethylformamide, $\mathrm{N}$-methylpyrrolidone (NMP), dimethylsulfoxide, $\mathrm{N}, \mathrm{N}$-dimethylacetamide (DMAc), pyridine- $\mathrm{N}$-oxide (py-O), 1,10-phenanthroline (phen), ethylenediamine (en) and dimethylimidazolidinone (DMI) as ligands. The weakly coordinating bis(trifluoromethylsulfonyl)imide was used as counter anion. Several compounds had a melting temperature below $100^{\circ} \mathrm{C}$, and the compound $\left[\mathrm{Co}(\mathrm{DMAc})_{6}\right]\left[\mathrm{Tf}_{2} \mathrm{~N}\right]_{2}$ was liquid at room temperature, with a viscosity of only $18 \mathrm{mPa} s$ at $80^{\circ} \mathrm{C}$. Several compounds were recrystallized to give high quality single crystals and their crystal structures were determined. EXAFS measurements were performed on $\left[\mathrm{Co}(\mathrm{DMAc})_{6}\right]\left[\mathrm{Tf}_{2} \mathrm{~N}\right]_{2}$ at different temperatures and it was observed that the $\left[\mathrm{Co}(\mathrm{DMAc})_{6}\right]^{2+}$ ion partially dissociated at higher temperatures, which explains the temperature-dependent color change (thermochromism). The electrochemical properties of the compounds with the lowest melting points were also investigated. Adherent, crack-free metallic cobalt layers could be electrodeposited from $\left[\mathrm{Co}(\mathrm{DMAc})_{6}\right]\left[\mathrm{Tf}_{2} \mathrm{~N}\right]_{2},\left[\mathrm{Co}(\mathrm{DMI})_{6}\right]\left[\mathrm{Tf}_{2} \mathrm{~N}\right]_{2}$ and $\left[\mathrm{Co}(\mathrm{NMP})_{6}\right]\left[\mathrm{Tf}_{2} \mathrm{~N}\right]_{2}$. From the first two, black deposits consisting of micrometer-sized needles were obtained, whereas the latter resulted in a dull grey cobalt layer consisting of micrometer-sized cobalt spheres. The $\mathrm{Co}(\mathrm{III}) / \mathrm{Co}$ (II) redox couple was not found to occur in any compound with an O-donor ligand, but the $\mathrm{Co}(\mathrm{III}) / \mathrm{Co}(\mathrm{II})$ redox couple was found to be quasi-reversible for $\left[\mathrm{Co}(\text { phen })_{3}\right]\left[\mathrm{Tf}_{2} \mathrm{~N}\right]_{2}$ dissolved in $[\mathrm{BMP}]\left[\mathrm{Tf}_{2} \mathrm{~N}\right]$.
\end{abstract}

Keywords: cobalt; electrodeposition; EXAFS; ionic liquids; N-donor ligands; O-donor ligands; thermochromism. 


\section{Introduction}

Ionic liquids are fascinating electrolytes for the electrodeposition of several metals due to their wide electrochemical window, intrinsic electrical conductivity and negligible vapor pressure at room temperature. ${ }^{1-7}$ Many metals that cannot be electrodeposited from aqueous solutions, can be deposited from ionic liquids. Although nickel and cobalt can be electrodeposited from aqueous plating baths, electrodeposition from non-aqueous electrolytes is still of interest because different morphologies of the cobalt deposits can be obtained..$^{8,9} \mathrm{~A}$ drawback of ionic liquids as electrolytes is their higher viscosity, leading to lower current densities. Also, many metal salts have a poor solubility in ionic liquids, especially when ionic liquids with weakly coordinating anions are used. Both issues can be solved by introducing the concept of "liquid metal salts" (LMS). ${ }^{10}$ In this type of ionic liquids, the metal is an integral part of the cation of the ionic liquid. This leads to high concentrations of metals in the electrolyte, without solubility issues. Since the metal is incorporated in the cation, it is electrostatically drawn towards the cathode during electrodeposition, counteracting the higher viscosity. Furthermore, since the cathodic breakdown reaction of the ionic liquid is the desired electrodeposition of the metal, uncontrolled decomposition products are not formed (provided that a sacrificial anode is being used), making the electrolyte bath more sustainable. Several ionic liquids that can be considered as liquid metal salts have been reported in the literature, ${ }^{11,12}$ including those containing silver(I), ${ }^{13,14}$ copper(I ${ }^{15}$ and copper(II), ${ }^{16,17}$ and cobalt(II). ${ }^{18}$ Electrodeposition from this type of compounds has been described. ${ }^{19-26}$ Our research group has investigated liquid metal salts in detail for high current density electrodeposition of metals. These liquid metal salts incorporated copper(I), ${ }^{10,27,28}$ zinc(II), ${ }^{29} \operatorname{tin}(\mathrm{II}),{ }^{30}$ silver(I), ${ }^{31-35}$ lithium(I), ${ }^{36}$ palladium(II), ${ }^{37}$ nickel(II), ${ }^{8}$ manganese(II) ${ }^{9}$ and cobalt(II). ${ }^{38,39}$

Many reports describe the electrodeposition of cobalt from non-aqueous electrolytes. Carlin et al. investigated the electrodeposition and nucleation of cobalt-aluminium alloys from a chloroaluminate molten salt mixture. ${ }^{40}$ Cobalt-zinc ${ }^{41-44}$ and cobalt-nickel ${ }^{45}$ alloys were electrodeposited from ureabased deep-eutectic solvents. Cobalt wires were electrodeposited from a cobalt chloride - [EMIM]Cl mixture ${ }^{46}$ (EMIM = 1-ethyl-3-methylimidazolium) and cobalt deposits were obtained from a urea choline chloride deep eutectic solvent. ${ }^{47}$ Cobalt electrodeposition from the ionic liquids

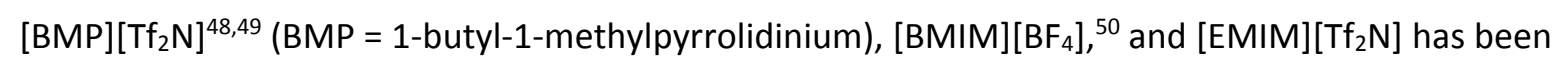
reported. ${ }^{51,52}$ The electrodeposition of cobalt from [BMP][Tf $\left.f_{2} \mathrm{~N}\right]$ was found to result in the simultaneous formation of Co films and Co nanoparticles..$^{53}$ Most current densities of the aforementioned cobalt deposition from non-aqueous electrolytes range from -0.1 to $-1 \mathrm{~A} \mathrm{dm}^{-2}$. The highest observed current density was -2.5 to $-3.0 \mathrm{~A} \mathrm{dm}^{-2}$, although technically this was nickel 
electrodeposition in which cobalt was co-deposited to form Ni-Co alloys. ${ }^{45}$ The highest observed current density for pure cobalt deposition from non-aqueous electrolytes was $-2 \mathrm{~A} \mathrm{dm}^{-2} .{ }^{47}$

In this work, cobalt(II) liquid metal salts are described, with ligands that, to the best of our knowledge, have not been used before to form liquid metal salts: $\mathrm{N}, \mathrm{N}$-dimethylformamide (DMF), $\mathrm{N}$-methylpyrrolidone (NMP), dimethylsulfoxide (DMSO), $\mathrm{N}, \mathrm{N}$-dimethylacetamide (DMAc), pyridine- $N$-oxide (py-O), 1,10-phenanthroline (phen), ethylenediamine (en) and 1,3-dimethyl-2imidazolidinone (DMI). The positive charge of the cobalt(II) center was balanced by two weakly coordinating bis(trifluoromethylsulfonyl)imide (bistriflimide, $\mathrm{Tf}_{2} \mathrm{~N}^{-}$) anions. 


\section{Experimental}

\section{General}

Cobalt(II) carbonate and all ligands (synthesis grade) were purchased from Sigma-Aldrich (Diegem, Belgium), whereas hydrogen bis(trifluoromethylsulfonyl)imide (80 wt\% aqueous solution) was purchased from loLiTec (Heilbronn, Germany). All chemical were used as received without any further purification. Melting points were determined on a Mettler-Toledo DSC 1 instrument, using a heating rate of $10^{\circ} \mathrm{C} \mathrm{min}-1$ under a helium atmosphere and analyzed using STARe software. Viscosities were measured using an Anton Paar LOVIS 2000 ME microviscometer. These measurements were only performed on compounds that were liquid at room temperature, since the use of this device requires careful filling of a capillary. Infrared spectra were recorded on a Bruker Vertex $70 \mathrm{FTIR}$ spectrometer with a resolution of $4 \mathrm{~cm}^{-1}$, in attenuated total reflectance (ATR) mode Assignments of the FTIR spectra were based on literature data. ${ }^{54-56} \mathrm{CHN}$ analysis was performed on a Thermo Scientific Flash 2000 Organic Elemental Analyzer. The morphology and elemental composition of the cobalt deposits were determined by scanning electron microscopy (SEM) on a Philips XL 30 FEG electron microscope equipped with energy-dispersive X-ray spectrometry (EDX).

\section{Electrochemistry}

Platinum-coated silicon wafers (Pt layer of $100 \mathrm{~nm}$ ) were used as working electrode. All electrodes were washed with $\mathrm{HCl}(36 \%)$ to remove possible impurities. Afterwards the electrodes were rinsed with demineralized water and acetone before drying. All electrochemical experiments were conducted in an argon-filled glovebox $\left(\mathrm{H}_{2} \mathrm{O}\right.$ and $\mathrm{O}_{2}$ concentrations below $\left.1 \mathrm{ppm}\right)$ and the electrolytes were dried overnight under vacuum at room temperature. Cyclic voltammograms were measured in an unstirred solution using an Autolab PGSTAT 302N electrochemical interface controlled by a computer with NOVA software. In order to make the cyclic voltammograms of these cobalt(II) liquid metal salts comparable to our previous work on other cobalt(II) and manganese(II) liquid metal salts, a reference electrode was constructed, consisting of a platinum wire, inserted in a solution of ferrocene $(5 \mathrm{mM})$ and ferrocenium $(5 \mathrm{mM})$ in the commercially available ionic liquid [BMP][Tf $2 \mathrm{~N}$ ]. The $\mathrm{Fc} /[\mathrm{BMP}]\left[\mathrm{Tf}_{2} \mathrm{~N}\right]$ reference compartment was closed off with a glass frit. As counter electrode, a cobalt plate was used. The surface area of the working electrode was $7 \mathrm{~mm} \times 7 \mathrm{~mm}$. Unless stated otherwise, all cyclic voltammograms were measured starting at open circuit potential (OCP) and scanning first in the cathodic direction. 


\section{Crystallography}

X-ray diffraction quality single crystals of all described compounds were obtained by crystallization from ethanol, acetonitrile, dichloromethane or acetone. [Co(phen) $\left.)_{3}\right]\left[\mathrm{Tf}_{2} \mathrm{~N}\right]_{2}$ was crystallized from acetonitrile with some toluene added, since this was necessary to obtain good quality crystals. The crystals were mounted on a nylon loop in the $\mathrm{N}_{2}(100(2) \mathrm{K})$ stream of an Oxford Cryostream 700 and irradiated using Mo K $\alpha$ radiation $(\lambda=0.71073 \AA$ ). Absorption corrections were applied using CrysAlisPro (Agilent Technologies, Yarnton, UK, 2011). Structures were solved using direct methods and refinement was performed by the full-matrix least-squares procedure in SHELXL using the graphical interface OLEX2. ${ }^{57-59}$ This software package was also used to generate images of the crystal structures. All hydrogen atoms were placed in calculated positions and refined using a riding model. CCDC numbers 1587585 - 1587590 contain all crystallographic data for the crystal structures described in this work. These data can be obtained free of charge from The Cambridge Crystallographic Data Centre via www.ccdc.cam.ac.uk/data_request/cif.

\section{EXAFS}

Extended X-ray Absorption Fine Structure (EXAFS) spectra of the Co K-edge were collected the Dutch-Belgian Beamline (DUBBLE, BM26A) at the European Synchrotron Radiation Facility (ESRF) in Grenoble (France). The energy of the X-ray beam was tuned by a double-crystal monochromator operating in fixed-exit mode using a Si(111) crystal pair. The measurements were performed in transmission mode using $\mathrm{Ar} / \mathrm{He}$ gas filled ionization chambers. A brass sample holder with Kapton ${ }^{\circledR}$ windows and a flexible polymeric spacer (VITON $\left.{ }^{\circledR}\right)$ with a thickness of $0.8 \mathrm{~mm}$ were used as a sample holder. Standard procedures were used for pre-edge subtraction and data normalization in order to isolate the EXAFS function $(\mathrm{X})$. The isolated EXAFS oscillations, accomplished by a smoothing spline as realized in the program Viper, ${ }^{60}$ were $k^{4}$-weighted and Fourier transformed over the $k$-range from \pm 2.5 to $\pm 14.5 \AA$ using a Gaussian Rounded ends window function. The data were fitted using the $a b$ initio code FEFF 7.0, ${ }^{61}$ which was used to calculate the theoretical phase and amplitude functions that subsequently were used in the non-linear least-squares refinement of the experimental data. Fitting of the data with the model was performed in $R$-space. Estimated standard deviations are shown between parentheses and calculated by VIPER.

In addition to the previous, for the construction of the model, the cif file of the crystal structure was used for the construction of the FEFF file. Five paths were included: four single scattering paths of cobalt(II) to $\mathrm{O}_{\alpha, 1}$, to $\mathrm{C}_{\alpha, 1}$, to $\mathrm{N}_{\alpha, 1}$ and to $\mathrm{C}_{\alpha, 1}$. Also one multiple scattering path was included: $\mathrm{Co}$ (II)$\mathrm{O}_{\alpha, 1}-\mathrm{N}_{\alpha, 1}$ and back. $\mathrm{S}_{0}$ was calibrated using the crystal structure of [Co(DMAc) $\left.)_{6}\right]\left[\mathrm{Tf}_{2} \mathrm{~N}\right]_{2}$ and was found 
to be 1.035 . It was optimized for the solid sample at room temperature and kept constant for the other fits.

\section{Synthesis}

\section{$\left[\mathrm{Co}(\mathrm{NMP})_{6}\right]\left[\mathrm{Tf}_{2} \mathrm{~N}\right]_{2}$}

The starting product $\left[\mathrm{Co}\left(\mathrm{H}_{2} \mathrm{O}\right)_{6}\right]\left[\mathrm{Tf}_{2} \mathrm{~N}\right]_{2}$ of all following syntheses was synthesized following a literature procedure ${ }^{39}$ To this starting product $(1.002 \mathrm{~g}, 1.378 \mathrm{mmol})$ in ethanol $(10 \mathrm{~mL})$ was added NMP ( $818 \mathrm{mg}, 8.251 \mathrm{mmol})$ and the mixture was stirred for five minutes. Ethanol was removed on the rotary evaporator. The product was further dried on a vacuum line over night at room temperature to give $\left[\mathrm{Co}(\mathrm{NMP})_{6}\right]\left[\mathrm{Tf}_{2} \mathrm{~N}\right]_{2}$ as a pink/purple crystalline solid. Yield: $1.618 \mathrm{~g}(1.333 \mathrm{mmol}$, 97 \%). CHN found (calculated) for $\mathrm{C}_{34} \mathrm{H}_{54} \mathrm{CoF}_{12} \mathrm{~N}_{8} \mathrm{O}_{14} \mathrm{~S}_{4}$ : C 33.42 (33.64) \%, H 4.52 (4.48) \%, N 9.12 (9.23). (ATR, $\left.\mathrm{V}_{\max } / \mathrm{cm}^{-1}\right): 2939\left(\mathrm{CH}_{3} \mathrm{~V}_{\mathrm{a}} \mathrm{C}-\mathrm{H}\right), 2885\left(\mathrm{CH}_{3} \mathrm{~V}_{\mathrm{s}} \mathrm{C}-\mathrm{H}\right), 1636$ (NMP coord. $\left.\mathrm{vC}=\mathrm{O}\right),(1513,1480$, $1457,1409)\left(v_{\text {ring }}\right), 1350\left(\mathrm{Tf}_{2} \mathrm{~N}^{-} v_{a} \mathrm{~S}=0\right), 1333$ ( $\left.v_{\text {ring }}\right), 1309\left(\mathrm{v}_{\mathrm{a}} \mathrm{S}=\mathrm{O}\right), 1263,(1228,1177)\left(\mathrm{v}_{\mathrm{a}} \mathrm{C}-\mathrm{F}\right), 1135$ $\left(v_{a} S=O\right), 1055\left(v_{a} S-N-S\right), 989,931,896,788(v C-S), 760,740\left(\delta_{s} F-C-F\right), 655,613,600,(569,511)\left(\delta_{a} F-C-\right.$ F), 482. Melting point: $70^{\circ} \mathrm{C}$.

\section{$\left[\mathrm{Co}(\mathrm{NEP})_{6}\right]\left[\mathrm{Tf}_{2} \mathrm{~N}\right]_{2}$}

To $\left[\mathrm{Co}\left(\mathrm{H}_{2} \mathrm{O}\right)_{6}\right]\left[\mathrm{Tf}_{2} \mathrm{~N}\right]_{2}(1.000 \mathrm{~g}, 1.375 \mathrm{mmol})$ in ethanol $(10 \mathrm{~mL})$ was added NEP $(934 \mathrm{mg}, 8.250 \mathrm{mmol})$ and the mixture was stirred for five minutes. Ethanol was removed on the rotary evaporator. The product was further dried on the vacuum line over night at room temperature to give $\left[\mathrm{Co}(\mathrm{NEP})_{6}\right]\left[\mathrm{Tf}_{2} \mathrm{~N}\right]_{2}$ as a pink/purple crystalline solid. Yield: $1.780 \mathrm{~g}(1.372 \mathrm{mmol}, 100 \%)$. CHN found (calculated) for $\mathrm{C}_{40} \mathrm{H}_{68} \mathrm{CoF}_{12} \mathrm{~N}_{8} \mathrm{O}_{15} \mathrm{~S}_{4}$ : C 36.74 (36.50) \%, H 5.39 (5.20) \%, N 8.49 (8.51). (ATR, $\mathrm{v}_{\max } / \mathrm{cm}^{-1}$ ): $2986\left(\mathrm{CH}_{3} v_{a} \mathrm{C}-\mathrm{H}\right), 2888\left(\mathrm{CH}_{3} \mathrm{~V}_{\mathrm{s}} \mathrm{C}-\mathrm{H}\right), 1633$ (NMP coord. vC=O), (1502, 1474, 1425) ( $\left.v_{\text {ring }}\right), 1386,1344$ $\left(v_{a} S=O\right), 1333\left(v_{\text {ring }}\right), 1319,1295(\delta C-H), 1275,(1226,1174)\left(v_{a} C-F\right), 1133\left(v_{a} S=0\right), 1087,1057\left(v_{a} S-N-\right.$ S), 1010, 948, 933, 854, 785 (vC-S), 739 ( $\left.\delta_{s} F-C-F\right), 651,615,597,(569,506)\left(\delta_{s} F-C-F\right)$, 434. Melting point: $57^{\circ} \mathrm{C}$.

\section{$\left[\mathrm{Co}(\mathrm{DMF})_{6}\right]\left[\mathrm{Tf}_{2} \mathrm{~N}\right]_{2}$}

To $\left[\mathrm{Co}\left(\mathrm{H}_{2} \mathrm{O}\right)_{6}\right]\left[\mathrm{Tf}_{2} \mathrm{~N}\right]_{2}(1.002 \mathrm{~g}, 1.378 \mathrm{mmol})$ in ethanol $(10 \mathrm{~mL})$ was added DMF (601 mg, $\left.8.223 \mathrm{mmol}\right)$ and the mixture was stirred for five minutes. Ethanol was removed on the rotary evaporator. The product was further dried on the vacuum line over night at room temperature to give [Co(DMF $\left.)_{6}\right]\left[\mathrm{Tf}_{2} \mathrm{~N}\right]_{2}$ as a pink/purple crystalline solid. Yield: $1.439 \mathrm{~g}(1.360 \mathrm{mmol}, 99 \%)$. CHN found (calculated) for $\mathrm{C}_{22} \mathrm{H}_{42} \mathrm{CoF}_{12} \mathrm{~N}_{8} \mathrm{O}_{14} \mathrm{~S}_{4}$ : C 24.82 (24.98) \%, H 4.28 (4.00) \%, N 10.48 (10.59). (ATR, 


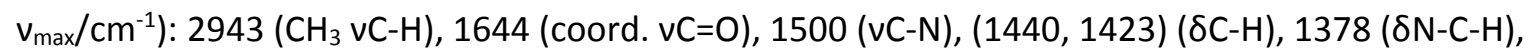

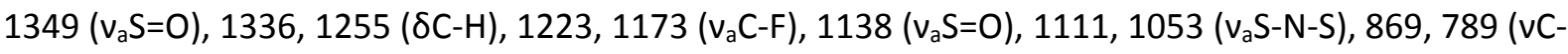
S), $761,740\left(\delta_{\mathrm{a}} \mathrm{F}-\mathrm{C}-\mathrm{F}\right), 685,657(\delta \mathrm{C}=0), 613,(569,513)\left(\delta_{\mathrm{s}} \mathrm{F}-\mathrm{C}-\mathrm{F}\right), 410(\omega \mathrm{S}=0)$. Melting point: $104^{\circ} \mathrm{C}$.

\section{$\left[\mathrm{Co}(\mathrm{DMAc})_{6}\right]\left[\mathrm{Tf}_{2} \mathrm{~N}\right]_{2}$}

To $\left[\mathrm{Co}\left(\mathrm{H}_{2} \mathrm{O}\right)_{6}\right]\left[\mathrm{Tf}_{2} \mathrm{~N}\right]_{2}(1.002 \mathrm{~g}, 1.378 \mathrm{mmol})$ in ethanol $(10 \mathrm{~mL})$ was added DMAc $(720 \mathrm{mg}, 8.264$ $\mathrm{mmol}$ ) and the mixture was stirred for five minutes. Ethanol was removed on the rotary evaporator. The product was further dried on the vacuum line over night at room temperature to give $\left[\mathrm{Co}(\mathrm{DMAc})_{6}\right]\left[\mathrm{Tf}_{2} \mathrm{~N}\right]_{2}$ as a purple/blue liquid. Yield: $1.570 \mathrm{~g}(1.374 \mathrm{mmol}, 100 \%)$. CHN found (calculated) for $\mathrm{C}_{28} \mathrm{H}_{58} \mathrm{CoF}_{12} \mathrm{~N}_{8} \mathrm{O}_{16} \mathrm{~S}_{4}$ : C 28.35 (28.55) \%, H 5.14 (4.96) \%, N 9.34 (9.51). (ATR, $v_{\max } / \mathrm{cm}^{-1}$ ):

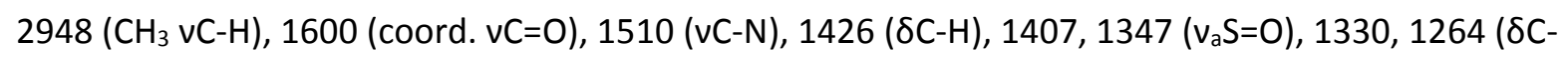

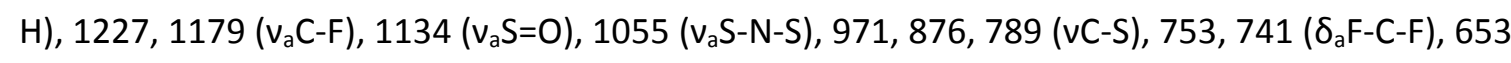
$(\delta \mathrm{C}=0), 614,601,(571,512)\left(\delta_{\mathrm{s}} \mathrm{F}-\mathrm{C}-\mathrm{F}\right), 487,444$. Glass transition temperature (cooling/heating): $55^{\circ} \mathrm{C} /-56^{\circ} \mathrm{C}$. Viscosity: $178 \mathrm{mPa} \mathrm{s}\left(25^{\circ} \mathrm{C}\right) ; 7 \mathrm{mPa}$ (extrapolated data to $120^{\circ} \mathrm{C}$ ).

\section{$\left[\mathrm{Co}(\mathrm{DMSO})_{6}\right]\left[\mathrm{Tf}_{2} \mathrm{~N}\right]_{2}$}

To $\left[\mathrm{Co}\left(\mathrm{H}_{2} \mathrm{O}\right)_{6}\right]\left[\mathrm{Tf}_{2} \mathrm{~N}\right]_{2}(0.997 \mathrm{~g}, 1.371 \mathrm{mmol})$ in ethanol $(10 \mathrm{~mL})$ was added DMSO $(941 \mathrm{mg}, 8.293$ $\mathrm{mmol}$ ) and the mixture was stirred for five minutes. Ethanol was removed on the rotary evaporator. The product was further dried on the vacuum line over night at room temperature to give [Co(DMSO) $\left.)_{6}\right]\left[\mathrm{Tf}_{2} \mathrm{~N}\right]_{2}$ as a pink/purple crystalline solid. Yield: $1.445 \mathrm{~g}(1.328 \mathrm{mmol}, 97 \%)$. CHN found (calculated) for $\mathrm{C}_{16} \mathrm{H}_{36} \mathrm{CoF}_{12} \mathrm{~N}_{2} \mathrm{O}_{14} \mathrm{~S}_{10}$ : $\mathrm{C} 17.55$ (17.66) \%, H 3.29 (3.34) \%, N 2.68 (2.57). (ATR, $\left.\mathrm{V}_{\max } / \mathrm{cm}^{-1}\right): 3483(\mathrm{VO}-\mathrm{H}), 2934\left(\mathrm{CH}_{3} \mathrm{~V}_{\mathrm{a}} \mathrm{C}-\mathrm{H}\right), 2874\left(\mathrm{CH}_{3} \mathrm{~V}_{\mathrm{s}} \mathrm{C}-\mathrm{H}\right), 1636(\delta \mathrm{H}-\mathrm{O}-\mathrm{H}), 1419(\delta \mathrm{C}-\mathrm{H}),(1346,1329)$ $\left(\mathrm{Tf}_{2} \mathrm{~N}^{-} \mathrm{v}_{\mathrm{a}} \mathrm{S}=\mathrm{O}\right),(1229,1178)\left(\mathrm{v}_{\mathrm{a}} \mathrm{C}-\mathrm{F}\right), 1132\left(\mathrm{Tf}_{2} \mathrm{~N}^{-} \mathrm{v}_{\mathrm{a}} \mathrm{S}=\mathrm{O}\right), 1056$ ( $\left.\mathrm{v}_{\mathrm{a}} \mathrm{S}-\mathrm{N}-\mathrm{S}\right), 995$ (DMSO coord. $\left.v \mathrm{~S}=0\right), 948$ ( $\rho \mathrm{H}-\mathrm{C}-\mathrm{H}), 788\left(\mathrm{Tf}_{2} \mathrm{~N}^{-} v \mathrm{C}-\mathrm{S}\right), 763,741\left(\delta_{\mathrm{s}} \mathrm{F}-\mathrm{C}-\mathrm{F}\right), 717$ (DMSO va $\left.\mathrm{C}-\mathrm{S}\right), 655,600,(570,504)\left(\delta_{\mathrm{a}} \mathrm{F}-\mathrm{C}-\mathrm{F}\right), 435$. Melting point: $97^{\circ} \mathrm{C}$.

\section{$\left[\mathrm{Co}(\mathrm{DMI})_{6}\right]\left[\mathrm{Tf}_{2} \mathrm{~N}\right]_{2}$}

To $\left[\mathrm{Co}\left(\mathrm{H}_{2} \mathrm{O}\right)_{6}\right]\left[\mathrm{Tf}_{2} \mathrm{~N}\right]_{2}(1.001 \mathrm{~g}, 1.377 \mathrm{mmol})$ in ethanol $(10 \mathrm{~mL})$ was added DMI (784 mg, $\left.6.870 \mathrm{mmol}\right)$ and the mixture was stirred for five minutes. Ethanol was removed on the rotary evaporator. The product was further dried on the vacuum line over night at room temperature to give $\left[\mathrm{Co}(\mathrm{DMI})_{5}\right]\left[\mathrm{Tf}_{2} \mathrm{~N}\right]_{2}$ as a purple viscous liquid. Yield: $1.620 \mathrm{~g}(1.362 \mathrm{mmol}, 99 \%) .\left(\mathrm{ATR}, \mathrm{v}_{\max } / \mathrm{cm}^{-1}\right): 2943$

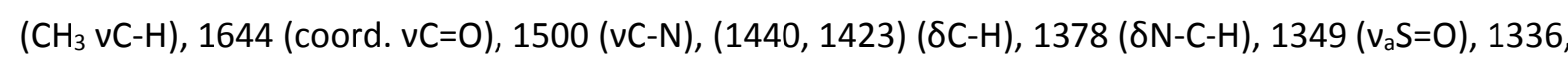
$1255(\delta C-H), 1223,1173\left(v_{a} C-F\right), 1138\left(v_{a} S=0\right), 1111,1053\left(v_{a} S-N-S\right), 869,789$ (vC-S), 761, $740\left(\delta_{a} F-C-\right.$ $\mathrm{F}), 685,657(\delta \mathrm{C}=\mathrm{O}), 613,(569,513)\left(\delta_{s} \mathrm{~F}-\mathrm{C}-\mathrm{F}\right), 410(\omega \mathrm{S}=0)$. Glass transition temperature (cooling/heating): $-55^{\circ} \mathrm{C} /-57^{\circ} \mathrm{C}$. Viscosity: $272 \mathrm{mPa} \mathrm{s}\left(25^{\circ} \mathrm{C}\right) ; 4 \mathrm{mPa}$ (extrapolated data to $120^{\circ} \mathrm{C}$ ). 


\section{$\left[\mathrm{Co}(\mathrm{py}-\mathrm{O})_{6}\right]\left[\mathrm{Tf}_{2} \mathrm{~N}\right]_{2}$}

To $\left[\mathrm{Co}\left(\mathrm{H}_{2} \mathrm{O}\right)_{6}\right]\left[\mathrm{Tf}_{2} \mathrm{~N}\right]_{2}(1.001 \mathrm{~g}, 1.377 \mathrm{mmol})$ in ethanol $(10 \mathrm{~mL})$ was added py-O $(783 \mathrm{mg}, 8.233 \mathrm{mmol})$ and the mixture was stirred for five minutes. Ethanol was removed on the rotary evaporator. The product was further dried on the vacuum line over night at room temperature to give [Co(py$\left.0)_{6}\right]\left[\mathrm{Tf}_{2} \mathrm{~N}\right]_{2}$ as a red crystalline solid. Yield: $1.499 \mathrm{~g}$ (1.370 mmol, $\left.100 \%\right)$. CHN found (calculated) for $\mathrm{C}_{34} \mathrm{H}_{30} \mathrm{CoF}_{12} \mathrm{~N}_{8} \mathrm{O}_{14} \mathrm{~S}_{4}$ : C 34.39 (34.32) \%, H 2.76 (2.54) \%, N 9.23 (9.42). (ATR, $\mathrm{v}_{\max } / \mathrm{cm}^{-1}$ ): 3122 (Ar. vC$H),(1611,1469)$ (ring def.), $(1346,1329)\left(v_{a} S=O\right),(1217,1172)\left(v_{a} C-F\right), 1131\left(v_{a} S=O\right), 1093$ (C-H in plane def.), 1059 ( $\mathrm{V}_{\mathrm{a}} \mathrm{S}-\mathrm{N}-\mathrm{S}$ ), 1022 (ring breathing), 915 (C-H out of plane def.), 834 ( $\left.\delta \mathrm{N}-\mathrm{O}\right), 789$ (VC-S), 769, $739\left(\delta_{s} F-C-F\right), 669,649,598,(570,556,508)\left(\delta_{a} F-C-F\right), 462,404(\omega S=0)$. Melting point: $144^{\circ} \mathrm{C}$.

\section{$\left[\mathrm{Co}(\mathrm{en})_{3}\right]\left[\mathrm{Tf}_{2} \mathrm{~N}\right]_{2}$}

To $\left[\mathrm{Co}\left(\mathrm{H}_{2} \mathrm{O}\right)_{6}\right]\left[\mathrm{Tf}_{2} \mathrm{~N}\right]_{2}(0.996 \mathrm{~g}, 1.369 \mathrm{mmol})$ in ethanol $(10 \mathrm{~mL})$ was added en $(128 \mathrm{mg}, 4.260 \mathrm{mmol})$ and the mixture was stirred for five minutes. Ethanol was removed on the rotary evaporator. The product was further dried on the vacuum line over night at room temperature to give [Co(en) $\left.{ }_{3}\right]\left[\mathrm{Tf}_{2} \mathrm{~N}\right]_{2}$ as a yellow/brown crystalline solid. Yield: $1.062 \mathrm{~g}(1.328 \mathrm{mmol}, 97 \%)$. CHN found (calculated) for $\mathrm{C}_{10} \mathrm{H}_{24} \mathrm{CoF}_{12} \mathrm{~N}_{8} \mathrm{O}_{8} \mathrm{~S}_{4}$ : $\mathrm{C} 15.09$ (15.02) \%, H 3.44 (3.03) \%, N 13.62 (14.02). (ATR, $\left.v_{\max } / \mathrm{cm}^{-1}\right)$ : (3356, 3304) $\left(\mathrm{V}_{\mathrm{a}, \mathrm{s}} \mathrm{N}-\mathrm{H}\right),(2963,2901)\left(\mathrm{v}_{\mathrm{a}, \mathrm{s}} \mathrm{C}-\mathrm{H}\right), 1596(\delta \mathrm{H}-\mathrm{N}-\mathrm{H}), 1467(\delta \mathrm{C}-\mathrm{H}), 1355\left(\mathrm{v}_{\mathrm{a}} \mathrm{S}=\mathrm{O}\right)$, 1333, 1217, 1182 ( $\left.\mathrm{v}_{\mathrm{a}} \mathrm{C}-\mathrm{F}\right), 1139$ (vS=O), 1052 ( $\left.\mathrm{v}_{\mathrm{a}} \mathrm{S}-\mathrm{N}-\mathrm{S}\right), 1021$ (vC-N), 1004, 969, 864, 792 (vC-S), 766 $\left(v_{s} S-N-S\right), 742\left(\delta_{s} F-C-F\right), 608\left(\delta_{a} \mathrm{O}=S=0\right),(569,512)\left(\delta_{a} F-C-F\right), 468,409(\omega S=0)$. Decomposes at $162{ }^{\circ} \mathrm{C}$.

\section{$\left[\mathrm{Co}(\text { phen })_{3}\right]\left[\mathrm{Tf}_{2} \mathrm{~N}\right]_{2}$}

To $\left[\mathrm{Co}\left(\mathrm{H}_{2} \mathrm{O}\right)_{6}\right]\left[\mathrm{Tf}_{2} \mathrm{~N}\right]_{2}(0.996 \mathrm{~g}, 1.369 \mathrm{mmol})$ in ethanol $(10 \mathrm{~mL})$ was added phen $\cdot \mathrm{H}_{2} \mathrm{O}(818 \mathrm{mg}, 4.126$ $\mathrm{mmol}$ ) and the mixture was stirred for five minutes. Ethanol was removed on the rotary evaporator. The product was further dried on the vacuum line over night at room temperature to give [Co(phen) $\left.)_{3}\right]\left[\mathrm{Tf}_{2} \mathrm{~N}\right]_{2}$ as a yellow crystalline solid. Yield: $1.530 \mathrm{~g}(1.320 \mathrm{mmol}, 96 \%)$. CHN found (calculated) for $\mathrm{C}_{40} \mathrm{H}_{24} \mathrm{CoF}_{12} \mathrm{~N}_{8} \mathrm{O}_{8} \mathrm{~S}_{4}$ : C 41.41 (41.42) \%, H 2.40 (2.09) \%, N 9.52 (9.66). (ATR, $\mathrm{v}_{\max } / \mathrm{cm}^{-1}$ ): 3072 (Ar. vC-H), 1739 (Ar. סC-H), 1628, 1583, 1519, (1497, 1457, 1427) (Ar. vC=C), 1343 (Ar. vC-N), $1330\left(v_{a} S=O\right), 1227,1179\left(v_{a} C-F\right), 1131$ (vS=O), 1105, 1054 ( $\left.v_{a} S-N-S\right),(868,843)$ (Ar. $\left.\delta C=C\right), 787$ (vC-S),

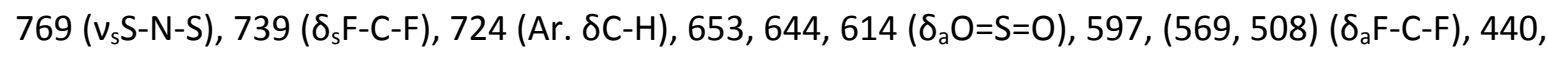
423, $406(\omega S=0)$. Melting point: $235^{\circ} \mathrm{C}$. 


\section{Results and Discussion}

\section{Synthesis and characterization}

For the synthesis of all the cobalt compounds in this work, the starting product $\mathrm{Co}\left(\mathrm{Tf}_{2} \mathrm{~N}\right)_{2} \cdot 6 \mathrm{H}_{2} \mathrm{O}$ was synthesized from $\mathrm{CoCO}_{3}$ and $\mathrm{HTf}_{2} \mathrm{~N}$. The starting product was dissolved in ethanol, to which a stoichiometric amount of the ligand was added. The ethanol was removed in vacuo and the resulting compound was dried on a Schlenk line overnight. The melting points varied: [Co(DMAc) $\left.{ }_{6}\right]\left[T f_{2} N\right]_{2}$ and $\left[\mathrm{Co}(\mathrm{DMI})_{6}\right]\left[\mathrm{Tf}_{2} \mathrm{~N}\right]_{2}$ were liquid at room temperature and could not be solidified on the timescale of the DSC experiment, whereas $\left[\mathrm{Co}(\mathrm{py}-\mathrm{O})_{3}\right]\left[\mathrm{Tf}_{2} \mathrm{~N}\right]_{2}$ had a melting point of $144{ }^{\circ} \mathrm{C}$. [Co $\left.(\mathrm{en})_{3}\right]\left[\mathrm{Tf}_{2} \mathrm{~N}\right]_{2}$ thermally decomposed without melting and $\left[\mathrm{Co}(\text { phen })_{3}\right]\left[\mathrm{Tf}_{2} \mathrm{~N}\right]_{2}$ had a melting point of $235^{\circ} \mathrm{C}$, making both compounds less interesting for applications. Interestingly, although $\left[\mathrm{Co}(\mathrm{DMAc})_{6}\right]\left[\mathrm{Tf}_{2} \mathrm{~N}_{2}\right.$ and $\left[\mathrm{Co}(\mathrm{DMF})_{6}\right]\left[\mathrm{Tf}_{2} \mathrm{~N}\right]_{2}$ differ only in one methyl group on the ligand, their melting points differ over $100^{\circ} \mathrm{C}$, with the compound with the dimethylacetamide ligands having the lower melting point.

\section{Color and thermochromism}

All compounds in which the cobalt(II) center is coordinated by an O-donor ligand were pink. Even the slightest deficiency of ligand causes the color of the compound to become darker pink to almost purple. $\left[\mathrm{Co}(\mathrm{DMAc})_{6}\right]\left[\mathrm{Tf}_{2} \mathrm{~N}\right]_{2}$ and $\left[\mathrm{Co}(\mathrm{DMI})_{6}\right]\left[\mathrm{Tf}_{2} \mathrm{~N}\right]_{2}$ were liquid at room temperature and these compounds had a dark blue to dark purple color. Compounds with an $\mathrm{N}$-donor ligand were yellow. For some cobalt(II) liquid metal salts with an O-donor ligand, a clear color change was observed upon heating the compound, i.e. these compounds show thermochromism. The color changed from light pink in the solid state, to dark purple in the liquid state at room temperature, to dark blue at $120^{\circ} \mathrm{C}$, where electrochemical experiments are conducted. When cooled down, the color returned to light pink. It was shown by temperature-dependent EXAFS measurements that this thermochromism arose from the loss of one or more ligands (vide infra).

Thermochromism has been observed for other cobalt(II)-containing ionic liquids in the past. For example for nitrile-functionalized pyrrolidinium ionic liquids, a temperature-dependent color change was observed which was attributed to loss of $\mathrm{H}_{2} \mathrm{O}$ ligands. ${ }^{62}$ When cobalt(II) chloride or nitrate was dissolved in an imidazolium ionic liquid with nitrate anions, no thermochromism was observed in the pure ionic liquid, but it was observed when water was added to the system. ${ }^{63}$ Also when cobalt(II) isothiocyanate was dissolved in [EMIM][SCN], a blue-to-pink color change was observed at $8{ }^{\circ} \mathrm{C} .{ }^{64,65}$ Thermochromism is also possible for other metal-containing ionic liquids, such as those with nickel(II) ${ }^{66,67}$ or uranyl isothiocyanate. ${ }^{68}$ 


\section{Crystallography}

The crystal structure of $\left[\mathrm{Co}(\mathrm{py}-\mathrm{O})_{6}\right]\left[\mathrm{Tf}_{2} \mathrm{~N}\right]_{2}$ was determined (Figure 1). The compound crystallized in the monoclinic space group $\mathrm{P} 2_{1} / n$. The cobalt atom was situated on an inversion center, and all the Co-O distances were of the same order of length, ranging from 2.0631(11) to 2.1051(12) Å. Due to the aromatic nature of the py-O ligand, several non-classical hydrogen bonds were observed, as well as several $\pi-\pi$ interactions $(5.0257(10)$ to $5.9237(10) \AA$, Table S1).

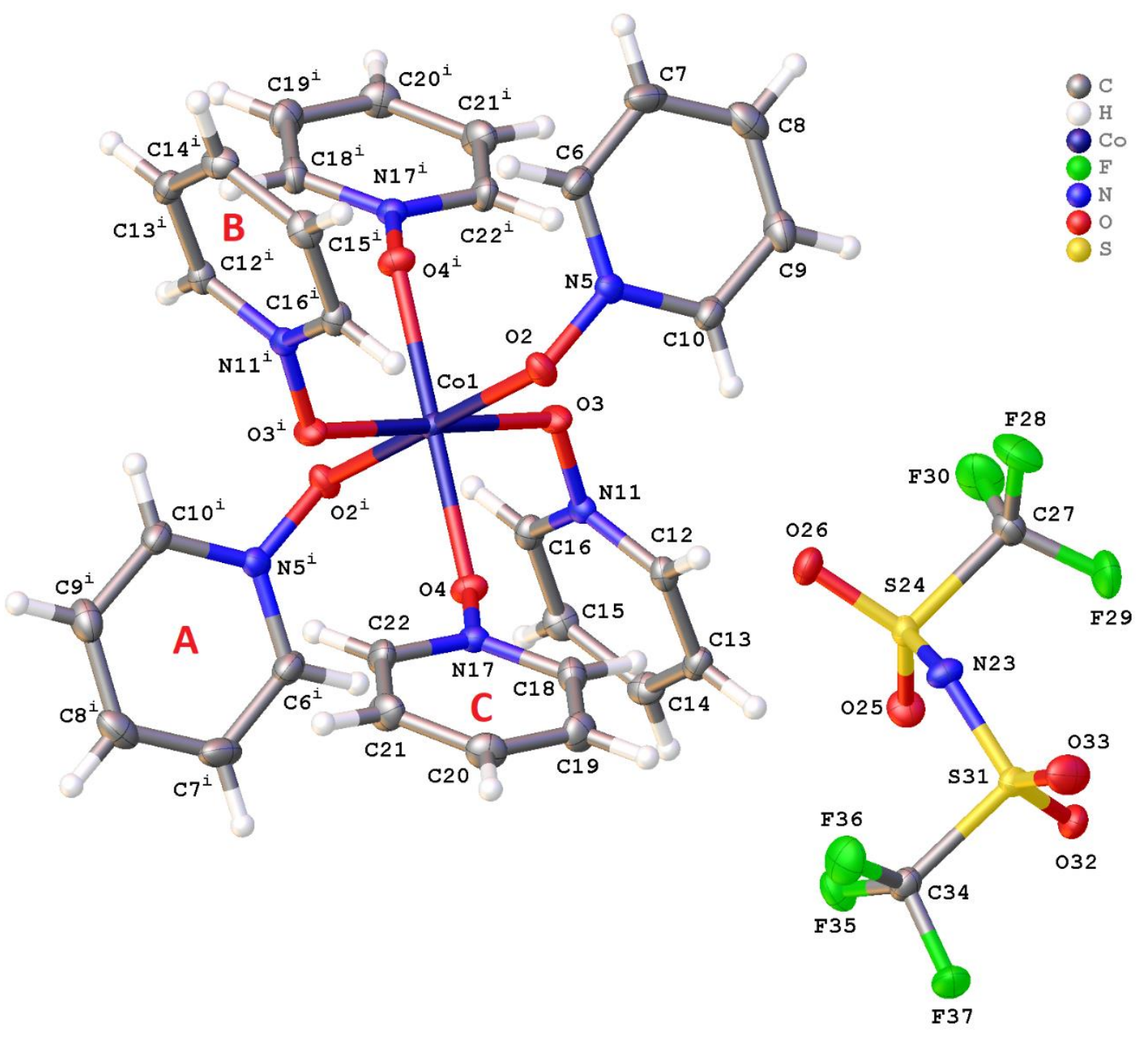

Figure 1: Crystal structure of [Co(py-O $\left.)_{6}\right]\left[\mathrm{Tf}_{2} \mathrm{~N}\right]_{2}$. Symmetry code: (i) 1-x, 1-y, 1-z. Displacement ellipsoids are drawn at the $50 \%$ probability level.

No melting point of $\left[\mathrm{Co}(\mathrm{DMAc})_{6}\right]\left[\mathrm{Tf}_{2} \mathrm{~N}\right]_{2}$ could be determined using DSC measurements since it melted before the sample pan could be inserted in the DSC apparatus. However, a crystal structure could be obtained by storing the compound on dry ice for several days and by immediately transferring a crystal from the frozen bulk to the cold stream of the X-ray diffractometer. The compound also crystallized in the monoclinic space group $P 2_{1} / n$, with two $\left[\mathrm{Co}_{0.5}(\mathrm{DMAc})_{3}\right]$ moieties on 
an inversion center and two half uncoordinating bis(trifluoromethylsulfonyl)imide anions completing the asymmetric unit (Figure S1). Co-O distances vary from 2.0579(14) to 2.1057(15) $\AA$ and C-H $\cdots \mathrm{X}$ interactions from 2.690(3) to 3.517(4) Å (Table S2).

The unit cell of $\left[\mathrm{Co}(\mathrm{NMP})_{6}\right]\left[\mathrm{Tf}_{2} \mathrm{~N}\right]_{2}$ consisted of a near perfect octahedral cobalt(II) center, coordinated by six NMP ligands (Co-O distances 2.094(13) to 2.1120(13) $\AA$ ), one full and two half non-coordinating bis(trifluoromethylsulfonyl)imide anions (Figure 2). All anions were disordered over two positions. A close-up of all anions showing greater detail on the disorder and atom numbering can be found in the supporting information (Figure S2). Non classical hydrogen bonds $\mathrm{C}-\mathrm{H} \cdots \mathrm{X}$ range from 2.841(3) to 3.354(5) Å.

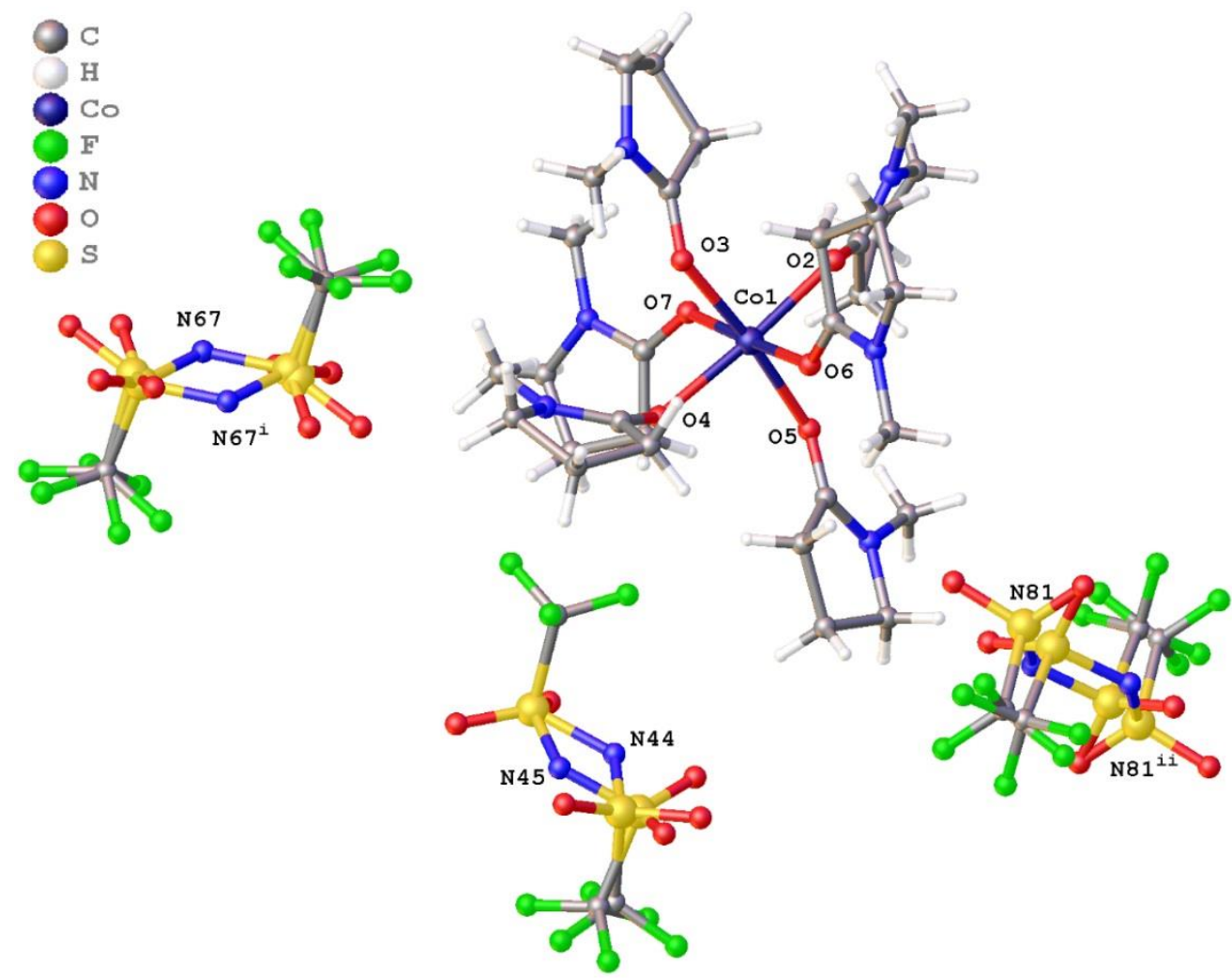

Figure 2: Crystal structure of $\left[\mathrm{Co}(\mathrm{NMP})_{6}\right]\left[\mathrm{Tf}_{2} \mathrm{~N}\right]_{2}$

A crystal structure of $\left[\mathrm{Co}(\mathrm{en})_{3}\right]\left[\mathrm{Tf}_{2} \mathrm{~N}\right]_{2}$ was also determined (Figure S3). The compound was disordered over two positions, which was to be expected since a $\lambda$ - and $\delta$ isomer of this compound can be formed. The unit cell consisted of one $\left[\mathrm{CO}_{0.5}(\mathrm{en})_{1.5}\right]$ moiety in which the ethylenediamine ligands are bidentate, and two half uncoordinating $\mathrm{Tf}_{2} \mathrm{~N}^{-}$anions. The nitrogen atom of one anion (N11) was situated on a twofold axis, whereas the other anion was located on an inversion center, 
hence the other two halves of both anions and the other $\left[\mathrm{Co}_{0.5}(\mathrm{en})_{1.5}\right]$ moiety are generated by symmetry operations. The Co-N distances were slightly larger than any of the previously measured Co-O distances (ranging from $1.159(8)$ to $2.182(3) \AA ̊$ ) and are very similar to those of cobalt(II) liquid metal salts with $N$-alkylimidazole ligands which have been reported earlier. ${ }^{39}$ There were only a few non-classical hydrogen bonds, from 3.140(4) to 3.316(4) ̊̊.

$\left[\mathrm{Co}(\text { phen })_{3}\right]\left[\mathrm{Tf}_{2} \mathrm{~N}\right]_{2}$ crystallized in the monoclinic space group $\mathrm{P} 2_{1} / c$ with each phenanthroline ligand bidentately coordinated to the cobalt(II) center (Figure 3). In the asymmetric unit, 2 cobalt(II) centers were present, as were 4 bis(trifluoromethylsulfonyl)imide anions and 1.5 molecules of toluene. Toluene was added to the crystallization solvent in order to obtain good quality single crystals No disorder on the anions is observed for this compound. The Co-N distances were shorter than those in [Co(en) $\left.)_{3}\right]\left[\mathrm{Tf}_{2} \mathrm{~N}\right]_{2}(2.111(2)$ to $2.146(2) \AA ̊)$, indicating that 1,10-phenanthroline is a more strongly coordinating ligand than ethylenediamine. Due to the very large number of aromatic rings in this crystal structure, there were over $150 \pi-\pi$ interactions, some as low as 3.6790(14) A. There were 15 $\mathrm{C}-\mathrm{H} \cdots \pi$ and $\mathrm{X}-\mathrm{Y} \cdots \pi$ interactions and $18 \mathrm{C}-\mathrm{H} \cdots \mathrm{X}$ non classical hydrogen bonds, ranging from $3.020(4)$ to 3.397(4) ^ (Table S2). The crystal structure of a similar cation was already published, with similar Co$\mathrm{N}$ distances, ${ }^{69}$ but in this case two perchlorate anions were used instead of the bis(trifluoromethylsulfonyl)imide anions presented here.

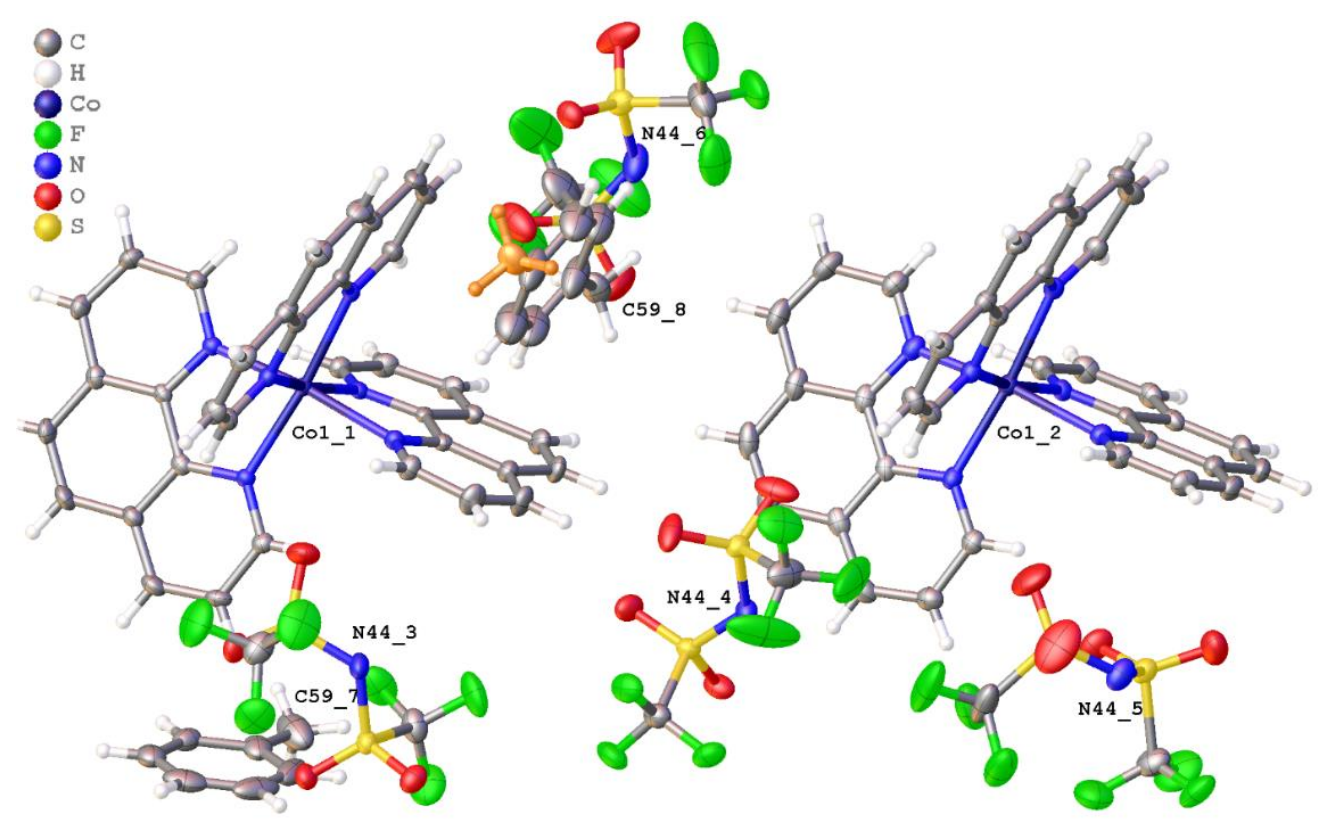

Figure 3: Crystal structure of $\left[\mathrm{Co}(\text { phen })_{3}\right]\left[\mathrm{Tf}_{2} \mathrm{~N}\right]_{2}$. Displacement ellipsoids are drawn at the $50 \%$ probability level 


\section{EXAFS}

Three different EXAFS measurements were performed on $\left[\mathrm{Co}(\mathrm{DMAc})_{6}\right]\left[\mathrm{Tf}_{2} \mathrm{~N}\right]_{2}$. The sample was measured at room temperature immediately after being kept $-78.5^{\circ} \mathrm{C}$, while it was still a solid. Since its melting temperature is below room temperature, the sample melted and EXAFS was measured again in the liquid state at room temperature and at $80^{\circ} \mathrm{C}$ (Figure 4 , further experimental data Figure S4 and Table S4). A pre-edge feature was present around $7712 \mathrm{keV}$, which is enlarged on the inset in the same figure. It showed an increase in the pre-edge feature with increasing temperature, whereas the height of the edge decreased with increasing temperature. Since the XANES pre-edge region is highly influenced by the coordination environment, these data already support the hypothesis of a temperature-dependent change in the coordination environment of the cobalt(II) center.

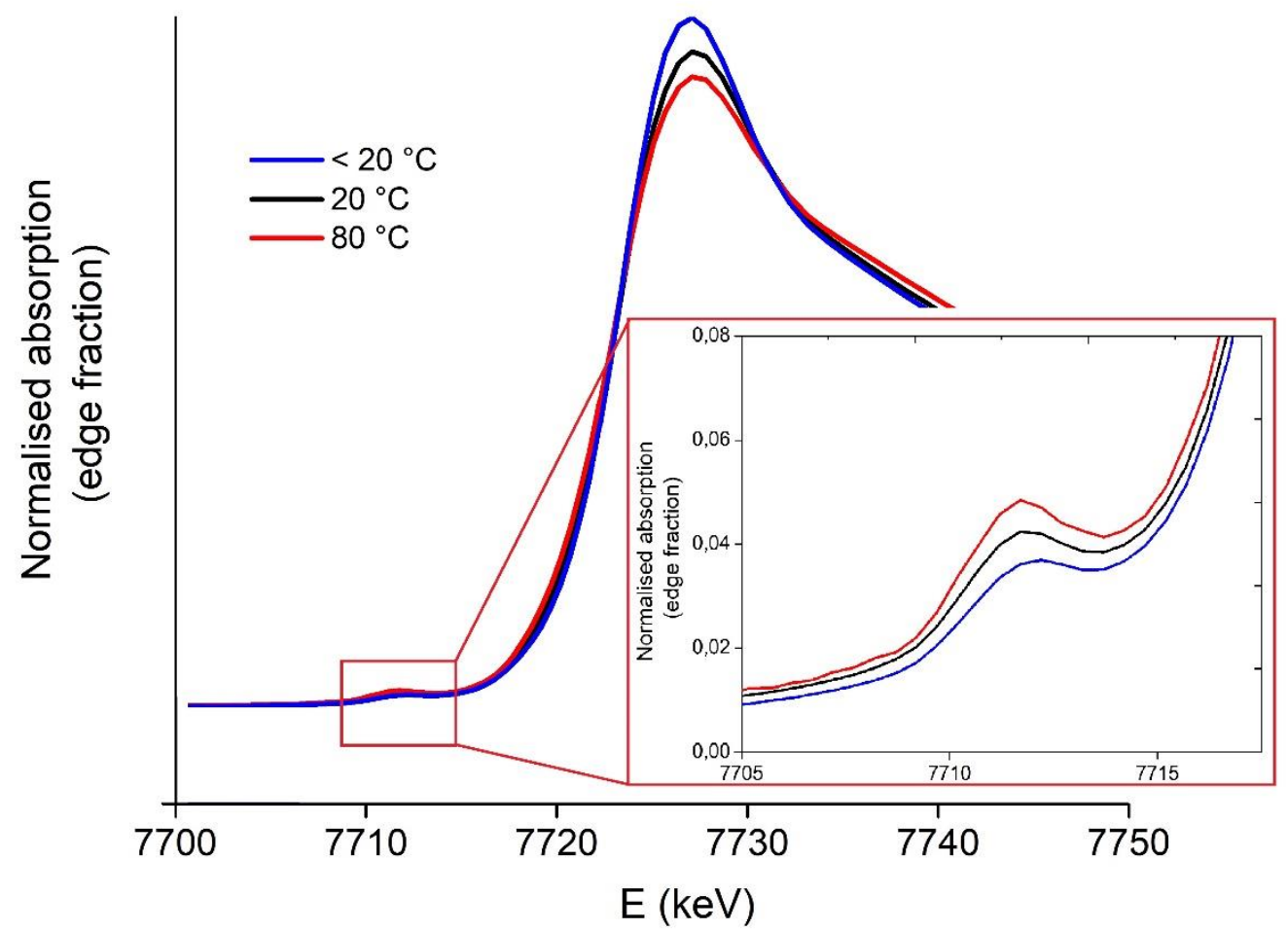

Figure 4: XANES region and absorption edge of the EXAFS spectrum of [Co(DMAc) $]\left[T f_{2} N\right]_{2}$. The inset shows a close-up of the pre-edge feature.

When the EXAFS spectra were Fourier-transformed to yield structural data, a few noteworthy differences were observed in the coordination environment of $\mathrm{Co}(\mathrm{II})$ in $\left[\mathrm{Co}(\mathrm{DMAc})_{6}\right]\left[\mathrm{Tf}_{2} \mathrm{~N}\right]_{2}$ at different temperatures. The average Co-O distance decreased from 2.075(2) ̊̊ for the solid

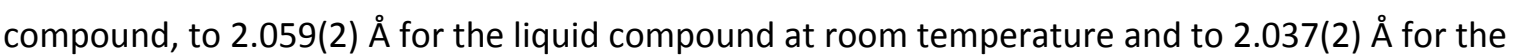
liquid compound at $80^{\circ} \mathrm{C}$. The coordination number decreased from $6.0(2)$ to $4.9(2)$. Obviously, the coordination number must always be an integer number, and there is a significant error in the calculation of the coordination number using EXAFS. However, based on the decrease in both 
coordination number and in the average Co-O distance, combined with the change in the pre-edge feature of the EXAFS spectra, we conclude that one or two ligands dissociate from the cobalt(II) ion at higher temperatures. This leads to a decrease in average coordination number, and since the twofold positive charge of the cobalt center is stabilized by fewer ligands, the average Co-O distance decreases. This also explains the color change: when cooled to $-78.5^{\circ} \mathrm{C}$, the compound was pink, whereas it turned dark purple to blue at higher temperatures. The same color change was also observed for other cobalt(II) compounds with O-donor ligands, hence it can be assumed that these compounds also lose one or more coordinated ligands at higher temperatures. The loss of one or two DMAc ligands was also observed in the literature before. ${ }^{70,71}$

\section{Electrodeposition of cobalt}

The compounds with the lowest melting points were investigated as electrolytes for the electrodeposition of cobalt. $\left[\mathrm{Co}(\mathrm{DMAc})_{6}\right]\left[\mathrm{Tf}_{2} \mathrm{~N}\right]_{2}$ had the lowest melting point and the lowest viscosity at room temperature of all these compounds $(178 \mathrm{mPa} s)$. When the viscosity data were measured at different temperatures and were extrapolated to $120^{\circ} \mathrm{C}$, this yielded the extremely low viscosity value of $7 \mathrm{mPa}$ s. Since several other compounds had a higher melting point and viscosity, a temperature of $120^{\circ} \mathrm{C}$ was chosen as working temperature for electrochemical experiments, in order to make all cyclic voltammograms (CVs) mutually comparable. A CV of [Co(DMAc) $)_{6}\left[\mathrm{Tf}_{2} \mathrm{~N}\right]_{2}$ is presented in Figure 5. It shows the typical deposition/stripping characteristics, with the electrodeposition of cobalt starting at about $-0.75 \mathrm{~V}$ vs Fc $/$ Fc. A nucleation loop is observed and there is no limiting current up to $-2.5 \mathrm{~V} \mathrm{vs} \mathrm{Fc}^{+} / \mathrm{Fc}$. The absence of a limiting current was observed before for other liquid metal salts of copper(I), silver(I), nickel(II), manganese(II), palladium(II) and lithium(I). ${ }^{10,27,28,31-36}$ Remarkable is the very high current densities that can be obtained from [Co(DMAc) $\left.)_{6}\right]\left[\mathrm{Tf}_{2} \mathrm{~N}\right]_{2}$, up to $-7 \mathrm{~A} \mathrm{dm}^{-2}$ at $-2.5 \mathrm{~V}$ vs $\mathrm{Fc}^{+} / \mathrm{Fc}$, which is much higher than for our previously published results on other divalent liquid metal salts such as nickel, manganese and cobalt, ${ }^{8,9,39}$ and which is also significantly higher than all non-aqueous electrolytes described in the literature, which rarely exceeded $-2.0 \mathrm{~A} \mathrm{dm}^{-2} .{ }^{47}$ Upon the reverse scan, there is only a small anodic peak related to the reoxidation of the deposited cobalt, hence the process is not electrochemically reversible. When a more negative vertex potential was selected, the cathodic current increased significantly, but the corresponding anodic current did not increase. This could indicates that the cathodic and anodic peak are not related, but this is unlikely since there is no other possible explanation for the anodic current except the oxidation of deposited cobalt. It is more likely that the process is irreversible due to the low coordinating abilities of the ligands. Oxygen-donor ligands have a smaller affinity for $\mathrm{Co}^{2+}$, and it is quite possible that the formation of the $\left[\mathrm{Co}(\mathrm{DMAc})_{6}\right]^{2+}$ cation is kinetically hindered, causing the absence of a larger anodic current in the cyclic voltammograms. This was observed as well in our 
previous work on manganese(II) liquid metal salts with weakly coordinating ligands. ${ }^{9}$ Other authors also reported on the non-reversibility of the $\mathrm{Co}(\mathrm{II}) / \mathrm{Co}(0)$ redox couple in ionic liquids or deepeutectic solvents, but no explanation was given for this phenomenon. ${ }^{40,42,49,51-53,72}$

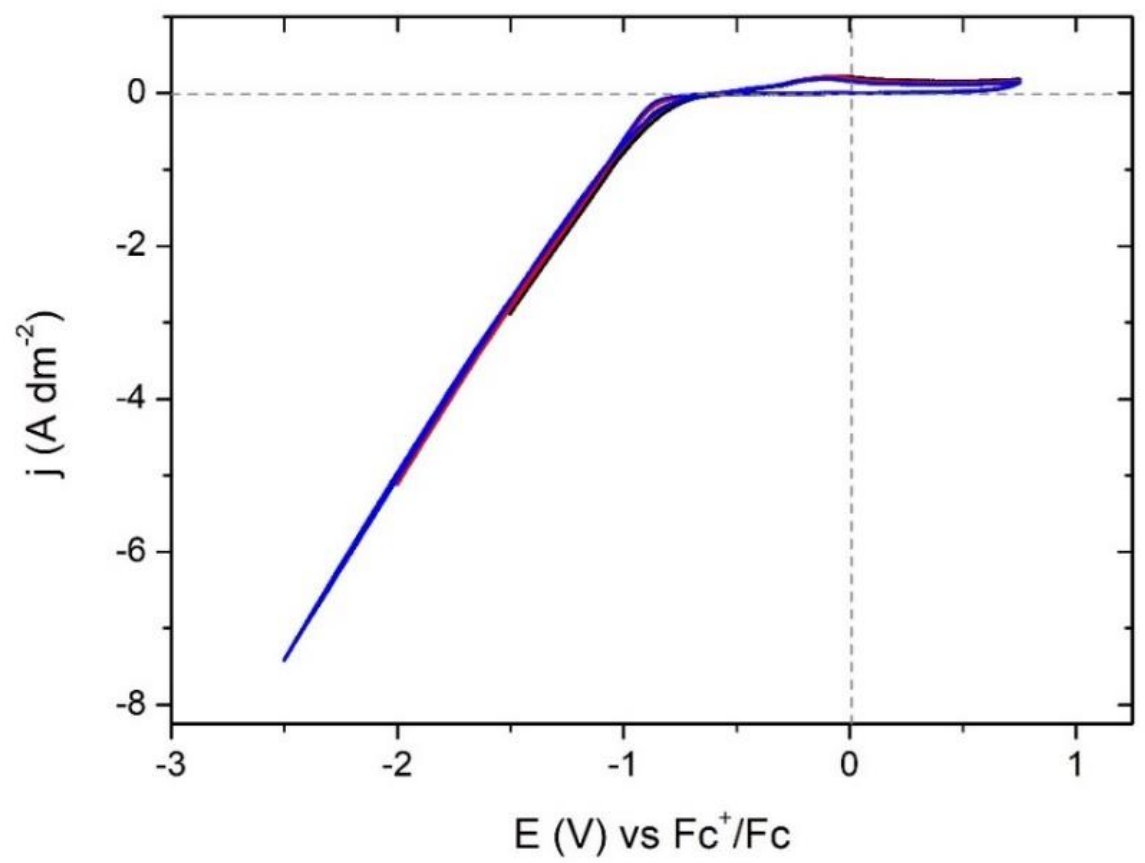

Figure 5: Cyclic voltammograms of $\left[\mathrm{Co}(D M A c)_{6}\right]\left[\mathrm{Tf}_{2} \mathrm{~N}\right]_{2}$ on a Pt-coated silicon wafer working electrode with varying cathodic vertex potentials. Black curve: $-1.5 \mathrm{~V} v s \mathrm{Fc}^{+} / \mathrm{Fc}$; red curve $-2.0 \mathrm{~V} v \mathrm{Fc} \mathrm{c}^{+} / \mathrm{Fc}$; blue curve: $-2.5 \mathrm{~V} v \mathrm{~s} \mathrm{Fc}^{+} / \mathrm{Fc}$. The scans were recorded with $v_{\text {scan }}=50 \mathrm{mV} \mathrm{s}^{-1}$ and at $T=120^{\circ} \mathrm{C}$, a cobalt plate was used as counter electrode and a platinum wire in an equimolar mixture of ferrocene/ferrocenium in $[B M P]\left[T f_{2} N\right]$ as reference electrode.

An important difference with our previous work on cobalt(II) liquid metal salts ${ }^{39}$ is that no electrochemical formation of cobalt(0) nanoparticles was observed in this case. The electrochemical nanoparticle formation was ascribed to a potential dependent adsorption of the cation to the working electrode, where $\mathrm{N}$-alkylimidazole ligands with a sufficiently long alkyl chain inhibited the formation of metal nuclei on the surface of the electrode. ${ }^{8,9,39}$ Since in this case no $\mathrm{N}$-alkylimidazole ligands were used, and the ligands were significantly less bulky than $N$-hexylimidazole, no nanoparticle formation was observed but cobalt deposits were obtained.

Very similar results were obtained for $\left[\mathrm{Co}(\mathrm{NMP})_{6}\right]\left[\mathrm{Tf}_{2} \mathrm{~N}\right]_{2}$ (Figure 6). In this case, the deposition of

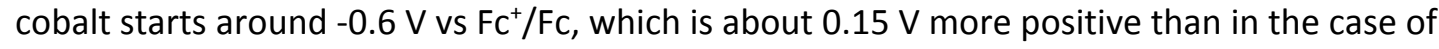
$\left[\mathrm{Co}(\mathrm{DMAc})_{6}\right]\left[\mathrm{Tf}_{2} \mathrm{~N}\right]_{2}$. Again no limiting current was observed, indicating that the process never enters a region of diffusion control. The current densities were again very high, similar to $\left[\mathrm{Co}(\mathrm{DMAc})_{6}\right]\left[\mathrm{Tf}_{2} \mathrm{~N}\right]_{2}$ and significantly higher than what was previously described for liquid metal salts with metal cations with a twofold positive charge..$^{8,9,37,39}$ The electrodeposition of cobalt was not reversible. 


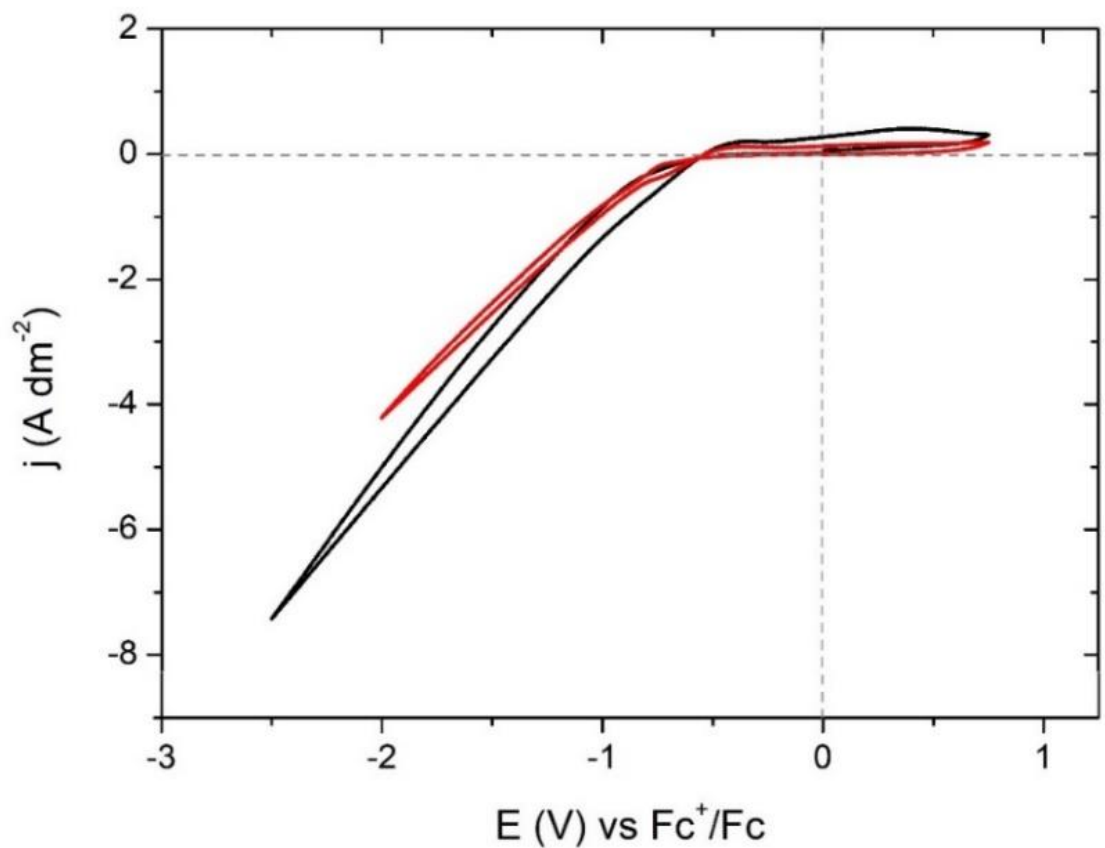

Figure 6: Cyclic voltammograms of $\left[\mathrm{CO}(\mathrm{NMP})_{6}\right]\left[\mathrm{Tf}_{2} \mathrm{~N}_{2}\right.$ on a Pt-coated silicon wafer working electrode with varying cathodic vertex potentials. Black curve: $-2.5 \mathrm{~V} v \mathrm{~F} \mathrm{c}^{+} / \mathrm{Fc}$ and red curve $-2.0 \mathrm{~V} v \mathrm{Fc}+\mathrm{Fc}$. The scans were recorded with $v_{\text {scan }}=50 \mathrm{mV} \mathrm{s}$ and at $T=120^{\circ} \mathrm{C}$, a cobalt plate was used as counter electrode and a platinum wire in an equimolar mixture of ferrocene/ferrocenium in $[B M P]\left[T f_{2} N\right]$ as reference electrode.

A cyclic voltammogram of $\left[\mathrm{Co}(\mathrm{DMI})_{6}\right]\left[\mathrm{Tf}_{2} \mathrm{~N}\right]_{2}$ was also measured (Figure 7). When the viscosity of this compound was extrapolated to $120^{\circ} \mathrm{C}$, a viscosity of only $4 \mathrm{mPa}$ s was obtained. Similar observations to the previous $\mathrm{CVs}$ were made. The process was not reversible, although there was a slightly larger anodic current at quite positive potentials (starting around $+0.25 \mathrm{~V} \mathrm{vs} \mathrm{Fc}^{+} / \mathrm{Fc}$ ) with a limiting current at $0.75 \mathrm{~V}$ vs $\mathrm{Fc}^{+} / \mathrm{Fc}$. The current density in general was lower than for the $\mathrm{CVs}$ described above, although it was still about 3 times higher than those previously reported for cobalt(II), manganese(II) and nickel(II) liquid metal salts. ${ }^{8,9,39}$ The electrodeposition of cobalt from all aforementioned liquid metal salts was irreversible since no oxidation of the deposited cobalt layer was observed. A drawback to this poor reversibility is that there is little control over the reaction that occurs at the counter electrode. Since cobalt is not easily oxidized, probably anodic degradation of the liquid metal salt occurs. Bis(trifluoromethylsulfonyl)imide anions can electrochemically be oxidized, ${ }^{73,74}$ however also the ligand can be oxidized. DMSO is probably the most resilient against oxidation, but DMF for example is rather easily oxidized. 


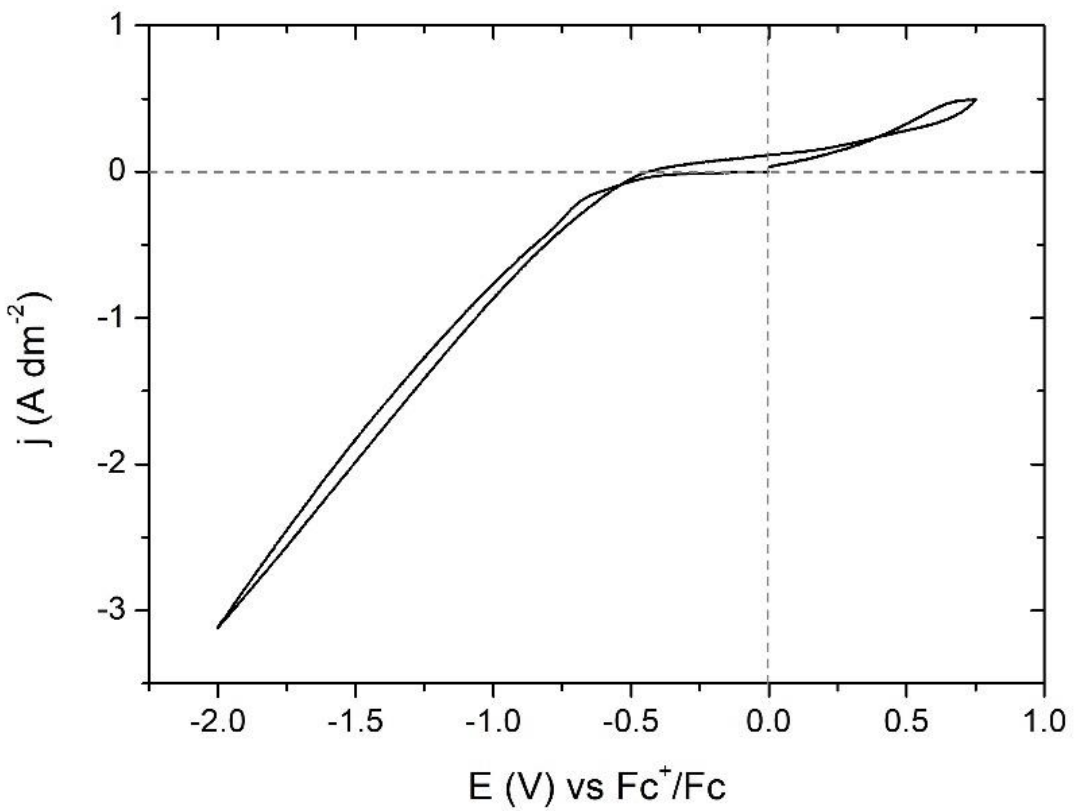

Figure 7: Cyclic voltammogram of $\left[\mathrm{Co}(\mathrm{DMI})_{6}\right]\left[\mathrm{Tf}_{2} \mathrm{~N}_{2}\right.$ on a Pt-coated silicon wafer working electrode. The scan was recorded with $v_{\text {scan }}=50 \mathrm{mV} \mathrm{s}^{-1}$ and at $T=120^{\circ} \mathrm{C}$, a cobalt plate was used as counter electrode and a platinum wire in an equimolar mixture of ferrocene/ferrocenium in $[B M P]\left[T f_{2} N\right]$ as reference electrode.

For the compounds $\left[\mathrm{Co}(\mathrm{DMSO})_{6}\right]\left[\mathrm{Tf}_{2} \mathrm{~N}\right]_{2}$ and $\left[\mathrm{Co}(\mathrm{DMF})_{6}\right]\left[\mathrm{Tf}_{2} \mathrm{~N}\right]_{2}$, which also have a reasonably low melting point, it was also tried to perform cyclic voltammetry measurements. However, since these compounds crystallized rapidly, a temperature of $120^{\circ} \mathrm{C}$ was not sufficiently high to avoid crystallization of the electrolyte on the electrodes. The bulk of the liquid was melted, but at the working and counter electrodes the electrolyte crystallized, and even a temperature of $150{ }^{\circ} \mathrm{C}$ was not sufficient to completely melt these compound. At even higher temperatures, too much thermal degradation of the liquid metal salt would occur, hence the electrochemistry of these compounds was not further investigated.

From $\left[\mathrm{Co}(\mathrm{DMAc})_{6}\right]\left[\mathrm{Tf}_{2} \mathrm{~N}\right]_{2},\left[\mathrm{Co}(\mathrm{NMP})_{6}\right]\left[\mathrm{Tf}_{2} \mathrm{~N}\right]_{2}$ and $\left[\mathrm{Co}(\mathrm{DMI})_{6}\right]\left[\mathrm{Tf}_{2} \mathrm{~N}\right]_{2}$, galvanostatic depositions were carried out in which the current was kept at $-1.0 \mathrm{~A} \mathrm{dm}^{-2}$ for 30 minutes (theoretical thickness $6.18 \mu \mathrm{m})$. The working electrode was rinsed afterwards with acetone and dried, and it was then examined by scanning electron microscopy (SEM) and energy-dispersive X-ray analysis (EDX). For $\left[\mathrm{Co}(\mathrm{DMAc})_{6}\right]\left[\mathrm{Tf}_{2} \mathrm{~N}\right]_{2}$ and $\left[\mathrm{Co}(\mathrm{NMP})_{6}\right]\left[\mathrm{Tf}_{2} \mathrm{~N}\right]_{2}$, a very dark black deposit was obtained, whereas for $\left[\mathrm{Co}(\mathrm{DMI})_{6}\right]\left[\mathrm{Tf}_{2} \mathrm{~N}\right]_{2}$, a dull grey metallic deposit was obtained. These differences in color of the deposit can be explained by examining the SEM images of these deposits. A SEM image of [Co(DMAc) $\left.{ }_{6}\right]\left[\mathrm{Tf}_{2} \mathrm{~N}\right]_{2}$ is presented in Figure 8 a) and b), and it can be seen that the deposits consist of micrometer-sized grains that completely cover the surface of the working electrode. Due to the surface morphology of this deposit, reminiscent of black nickel coatings for solar heat absorption, most of the incident light is absorbed in the micrometer sized pores. Similar considerations hold for deposits from 
$\left[\mathrm{Co}(\mathrm{NMP})_{6}\right]\left[\mathrm{Tf}_{2} \mathrm{~N}\right]_{2}$, (Figure $8 \mathrm{c}$ ) and d) of which the micrometer-sized grains consist of randomly stacked platelets. The deposits from $\left[\mathrm{Co}(\mathrm{DMI})_{6}\right]\left[\mathrm{Tf}_{2} \mathrm{~N}\right]_{2}$ consist of micrometer-sized spheres (Figure 8 e) and f). These deposits have a smaller surface and less edges between the micrometer sized grains, hence the dull, grey, metallic appearance of the deposit.
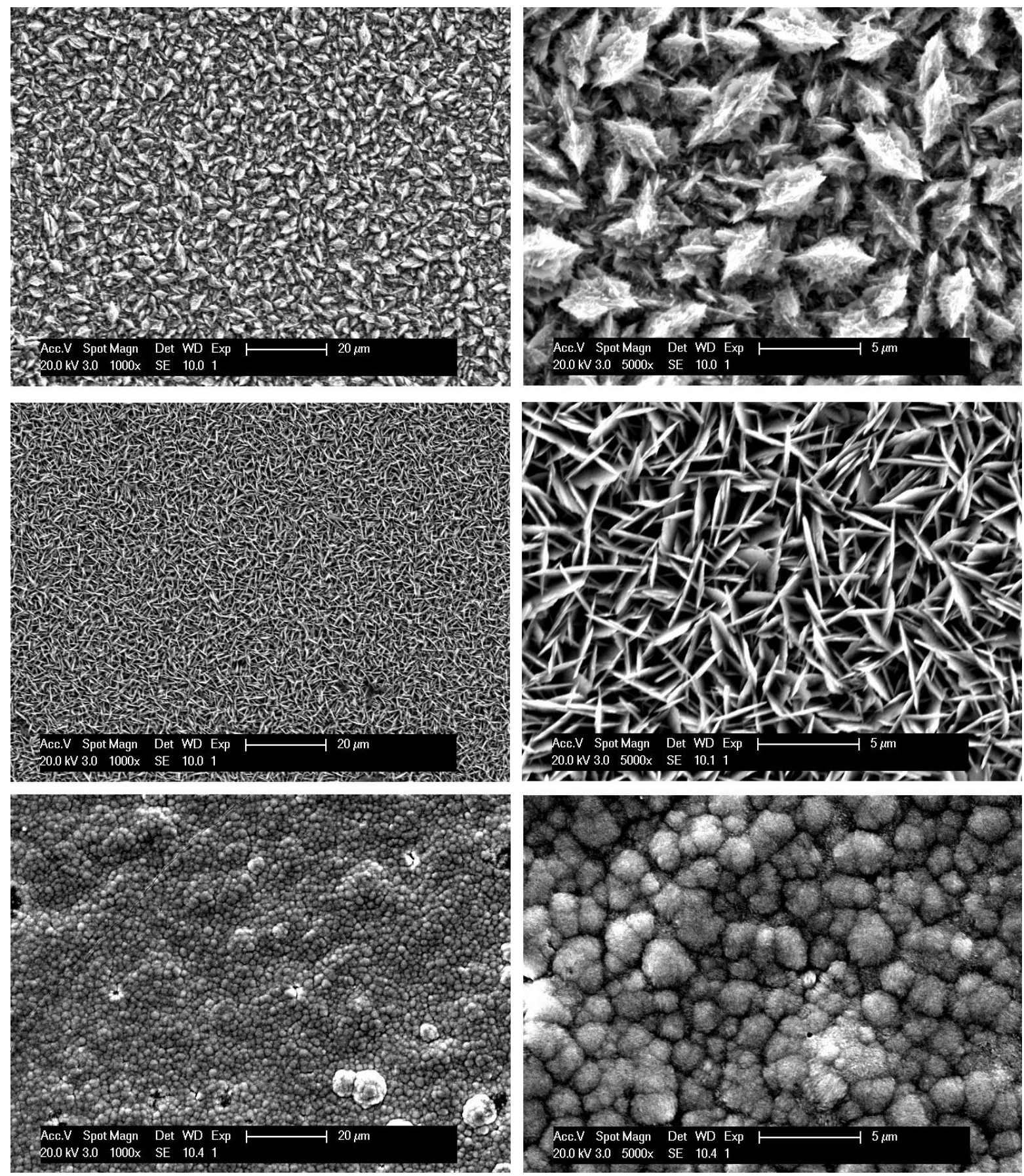

Figure 8: SEM images of $\left[\mathrm{Co}(D M A c)_{6}\right]\left[T f_{2} N\right]_{2}$ (a and $b$, top) $\left[\mathrm{Co}(N M P)_{6}\right]\left[T f_{2} N\right]_{2}\left(c\right.$ and d, middle) and $\left[\mathrm{Co}(D M I)_{6}\right]\left[T f_{2} N\right]_{2}(e$ and $f$, bottom) after galvanostatic electrodeposition at $-1.0 \mathrm{~A} \mathrm{dm}^{-2}$ for 30 minutes. 
Energy dispersive X-ray measurements were performed on the deposits (Figure S5), and no other peaks than those of cobalt were found, indicating that the deposits consisted of pure cobalt $(0)$. Since not even platinum or silicon was found (from the working electrode), the coverage of the working electrode was complete and the deposit was sufficiently thick.

None of the aforementioned cyclic voltammograms showed the presence of the $\mathrm{Co}^{3+} / \mathrm{Co}^{2+}$ redox couple. Because $\mathrm{Co}^{3+}$ is a strong oxidizing ion and is a hard Lewis acid, it can only be stabilized by a few ligands, and DMAc, NMP and DMI are not amongst them. $\mathrm{Co}^{3+}$ is usually stabilized by $\mathrm{N}$-donor ligands. Therefore, the 1,10-phenanthroline (phen) ligand was selected, and the Co(II) compound $\left[\mathrm{Co}(\text { phen })_{3}\right]\left[\mathrm{Tf}_{2} \mathrm{~N}\right]_{2}$ was synthesized, with a melting point of $235^{\circ} \mathrm{C}$. When this compound was dissolved in the ionic liquid [BMP][Tf $\left.f_{2} \mathrm{~N}\right](10 \mathrm{mM})$, several redox couples were observed (Figure 9). A very similar cyclic voltammogram has been reported by Xing et al. ${ }^{75}$ who dissolved [Co(phen $\left.)_{3}\right]\left[\mathrm{PF}_{6}\right]_{2}$ in acetonitrile. Whereas our system contains a different anion and was dissolved in an ionic liquid rather than in a molecular organic solvent, the cation under observation is the same, hence similarities between both CVs were expected. Xing et al. ${ }^{75}$ observed the same three redox couples as we observe here: the $\mathrm{Co}^{3+} / \mathrm{Co}^{2+}$ redox couple, which is in our case situated around $+0.6 \mathrm{~V} v s$ cobalt. The $\mathrm{Co}^{2+} / \mathrm{Co}^{+}$redox couple which is situated around $-0.75 \mathrm{~V}$ vs cobalt and the $\mathrm{Co}^{+} / \mathrm{Co}^{0}$ redox couple which is situated around $-1.4 \mathrm{~V}$ vs cobalt (Figure 9 top). In the bottom figure in Figure 9 , the $\mathrm{Co}^{3+} / \mathrm{Co}^{2+}$ redox couple was further investigated by using different scan rates in the CV. There is only a slight increase in peak potential with increasing scan rates, hence the $\mathrm{Co}^{3+} / \mathrm{Co}^{2+}$ redox couple can be qualified as quasi-reversible. 

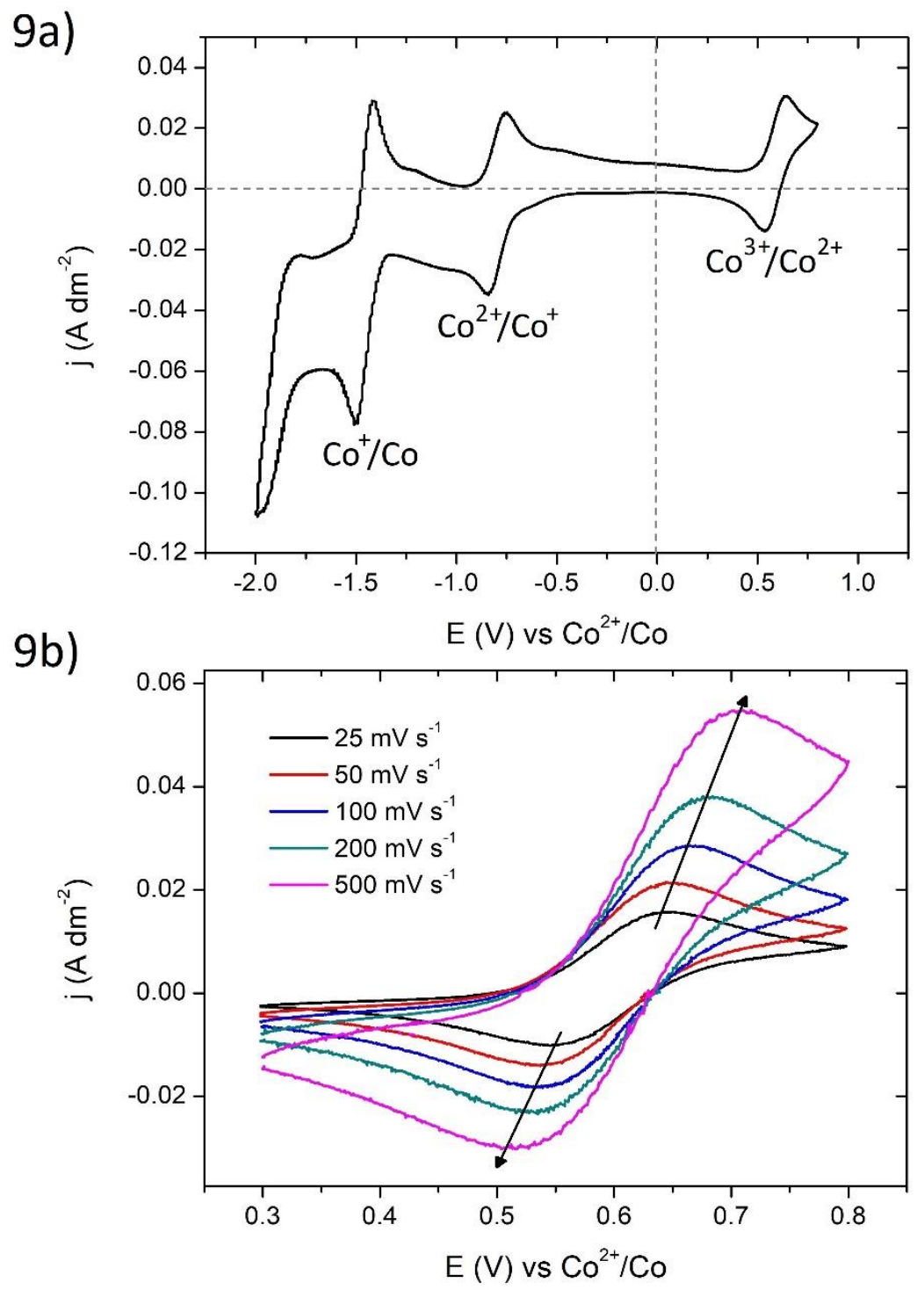

Figure 9: Cyclic voltammograms of [Co(phen) $\left.)_{3}\right]\left[\mathrm{Tf}_{2} \mathrm{~N}\right]_{2}(0.01 \mathrm{M})$ in $[B M P]\left[\mathrm{Tf}_{2} \mathrm{~N}\right]$ on a Pt-coated silicon wafer working electrode. The scan was recorded with $v_{\text {scan }}=50 \mathrm{mV} \mathrm{s}^{-1}$ (top) and at varying scan rates (bottom). $T=80^{\circ} \mathrm{C}$, a cobalt plate was used as counter electrode and another cobalt plate as pseudo-reference electrode.

\section{Conclusions}

New cobalt(II) liquid metal salts were synthesized which structurally differed strongly from previously reported compounds with $\mathrm{N}$-alkylimidazole ligands and this resulted in significantly different properties. Crystal structures of $\left[\mathrm{Co}(\mathrm{DMSO})_{6}\right]\left[\mathrm{Tf}_{2} \mathrm{~N}\right]_{2},\left[\mathrm{Co}(\text { py-O })_{6}\right]\left[\mathrm{Tf}_{2} \mathrm{~N}\right]_{2},\left[\mathrm{Co}(\mathrm{DMAc})_{6}\right]\left[\mathrm{Tf}_{2} \mathrm{~N}\right]_{2}$, $\left[\mathrm{Co}(\mathrm{NMP})_{6}\right]\left[\mathrm{Tf}_{2} \mathrm{~N}\right]_{2},\left[\mathrm{Co}(\mathrm{en})_{3}\right]\left[\mathrm{Tf}_{2} \mathrm{~N}\right]_{2}$ and $\left[\mathrm{Co}(\text { phen })_{3}\right]\left[\mathrm{Tf}_{2} \mathrm{~N}\right]_{2}$ were reported. Thermochromism of several compounds was observed upon heating. Temperature-dependent EXAFS measurements on $\left[\mathrm{Co}(\mathrm{DMAC})_{6}\right]\left[\mathrm{Tf}_{2} \mathrm{~N}\right]_{2}$ revealed a change in coordination environment of $\mathrm{Co}(\mathrm{II})$ at different temperatures, which was related to a loss of one or two ligands, causing the color change. Cobalt deposits could be obtained from $\left[\mathrm{Co}(\mathrm{DMAc})_{6}\right]\left[\mathrm{Tf}_{2} \mathrm{~N}\right]_{2}$, $\left[\mathrm{Co}(\mathrm{NMP})_{6}\right]\left[\mathrm{Tf}_{2} \mathrm{~N}\right]_{2}$ and $\left[\mathrm{Co}(\mathrm{DMI})_{6}\right]\left[\mathrm{Tf}_{2} \mathrm{~N}\right]_{2}$ at current densities up to 8 times higher than previously reported for any liquid metal salt with divalent 
metal ions. The deposits from the $\left[\mathrm{Co}(\mathrm{DMAc})_{6}\right]\left[\mathrm{Tf}_{2} \mathrm{~N}\right]_{2}$ and $\left[\mathrm{Co}(\mathrm{NMP})_{6}\right]\left[\mathrm{Tf}_{2} \mathrm{~N}\right]_{2}$ electrolytes showed microscopic substructures that absorbed a substantial amount of the visible light, leading to black deposits. From the $\left[\mathrm{Co}(\mathrm{DMI})_{6}\right]\left[\mathrm{Tf}_{2} \mathrm{~N}\right]_{2}$ electrolyte, dull grey cobalt deposits were obtained. All deposits were crack-free and consisted of pure cobalt metal. The $\mathrm{Co}^{3+} / \mathrm{Co}^{2+}$ redox couple was found to be quasi-reversible in $\left[\mathrm{Co}(\text { phen })_{3}\right]\left[\mathrm{Tf}_{2} \mathrm{~N}\right]_{2}$ dissolved in the ionic liquid $[\mathrm{BMP}]\left[\mathrm{Tf}_{2} \mathrm{~N}\right]$, which was the only compound that showed the presence of the cobalt(0), cobalt(I), cobalt(II) and cobalt(III) oxidation states.

\section{Conflicts of interest}

There are no conflicts to declare.

\section{Acknowledgements}

The authors acknowledge financial support by the FWO-Flanders (research project G.0B9613.N) and KU Leuven (project IDO/12/006 IREBAT). The authors want to thank the FWO-Flanders and the DUBBLE staff for financial and technical support at the DUBBLE EXAFS beamline. TVDH wants to thank the FWO-Flanders for his postdoctoral fellowship. The help of Dirk Henot with CHN measurements is greatly appreciated. The Hercules Foundation is acknowledged for providing funding for an X-ray diffractometer through project AKUL/09/0035.

\section{References}

1 K. R. Seddon, J. Chem. Technol. Biotechnol., 1997, 68, 351-356.

2 N. V Plechkova and K. R. Seddon, Chem. Soc. Rev., 2008, 37, 123-150.

3 T. Welton, Chem. Rev., 1999, 99, 2071-2083.

$4 \quad$ P. Wasserscheid and W. Keim, Angew. Chem. Int. Ed. Engl., 2000, 39, 3772-3789.

5 P. A. Z. Suarez, V. M. Selbach, J. E. L. Dullius, S. Einloft, C. M. S. Piatnicki, D. S. Azambuja, R. F. de Souza and J. Dupont, Electrochim. Acta, 1997, 42, 2533-2535.

6 A. M. O. Mahony, D. S. Silvester, L. Aldous, C. Hardacre and R. G. Compton, Engineering, 2008, 2884-2891.

7 F. Endres, ChemPhysChem, 2002, 3, 144-154.

8 J. Sniekers, K. Verguts, N. R. Brooks, S. Schaltin, T. H. Phan, T. M. Trung Huynh, L. Van Meervelt, S. Defeyter, J. W. Seo, J. Fransaer and K. Binnemans, Chem. - A Eur. J., 2016, 22, 1010-1020. 
9 J. Sniekers, J. C. Malaquias, L. Van Meervelt, J. Fransaer and K. Binnemans, Dalt. Trans., 2017, 46, 2497-2509.

10 N. R. Brooks, S. Schaltin, K. Van Hecke, L. Van Meervelt, K. Binnemans and J. Fransaer, Chem. Eur. J., 2011, 17, 5054-5059.

11 J. A. Welleman, F. B. Hulsbergen, J. Verbiest and J. Reedijk, J. Inorg. Nucl. Chem., 1978, 40, 143-147.

12 T. Vander Hoogerstraete, N. R. Brooks, B. Norberg, J. Wouters, K. Van Hecke, L. Van Meervelt and K. Binnemans, CrystEngComm, 2012, 14, 4902-4911.

13 A. Cingolani, F. Marchetti, C. Pettinari, B. W. Skelton and A. H. White, J. Chem. Soc. Dalt. Trans., 1999, 4047-4055.

14 A. C. Albéniz, J. Barbera, P. Espinet, C. M. Lequerica, A. M. Levelut, F. J. Lopez-Marcos and J. L. Serrano, Eur. J. Inorg. Chem., 2000, 133-138.

15 Y. Funasako, T. Mochida, K. Takahashi, T. Sakurai and H. Ohta, Chem. - A Eur. J., 2012, 18, 11929-11936.

Y. Funasako, M. Nosho and T. Mochida, Dalt. Trans., 2013, 42, 10138-10143.

17 R. Horikoshi, Y. Funasako, T. Yajima, T. Mochida, Y. Kobayashi and H. Kageyama, Polyhedron, $2013,50,66-74$.

18 T. Mochida, Y. Funasako, T. Inagaki, M. J. Li, K. Asahara and D. Kuwahara, Chem. - A Eur. J., $2013,19,6257-6264$.

19 A. P. Abbott, G. Capper, D. L. Davies and R. K. Rasheed, Chem. Eur. J., 2004, 10, 3769-3774.

20 J. Huang, H. Luo and S. Dai, J. Electrochem. Soc., 2006, 153, J9-J13.

21 M. lida, C. Baba, M. Inoue, H. Yoshida, E. Taguchi and H. Furusho, Chem. Eur. J., 2008, 14, 5047-5056.

22 M. lida, S. Kawakami, E. Syouno, H. Er and E. Taguchi, J. Colloid Interface Sci., 2011, 356, 630638.

23 H. D. Pratt, D. Ingersoll, N. S. Hudak, B. B. McKenzie and T. M. Anderson, J. Electroanal. Chem., 2013, 704, 153-158.

24 T. M. Anderson, D. Ingersoll, A. J. Rose, C. L. Staiger and J. C. Leonard, Dalton Trans., 2010, 39, 8609-8612. 

3525.

H. D. Pratt, A. J. Rose, C. L. Staiger, D. Ingersoll and T. M. Anderson, Dalton Trans., 2011, 40, 11396-11401.

27 S. Schaltin, N. R. Brooks, K. Binnemans and J. Fransaer, J. Electrochem. Soc., 2011, 158, D21D27.

28 S. Schaltin, N. R. Brooks, L. Stappers, L. D’Urzo, H. Plank, C. Gspan, K. Binnemans and J. Fransaer, J. Electrochem. Soc., 2011, 158, D647-D650.

M. Steichen, N. R. Brooks, L. Van Meervelt, J. Fransaer and K. Binnemans, Dalt. Trans., 2014, 43, 12329-12341.

M. Steichen, J. C. Malaquias, M. Arasimowicz, R. Djemour, N. R. Brooks, L. Van Meervelt, J. Fransaer, K. Binnemans and P. J. Dale, Chem. Commun., 2017, 53, 913-916.

J. Sniekers, N. R. Brooks, S. Schaltin, L. Van Meervelt, J. Fransaer and K. Binnemans, Dalt. trans., 2014, 43, 1589-1598.

N. R. Brooks, S. Schaltin, K. Van Hecke, L. Van Meervelt, J. Fransaer and K. Binnemans, Dalton Trans., 2012, 41, 6902-6905.

S. Schaltin, N. R. Brooks, L. Stappers, K. Van Hecke, L. Van Meervelt, K. Binnemans and J. Fransaer, Phys. Chem. Chem. Phys., 2012, 14, 1706-1715.

34 D. Depuydt, N. R. Brooks, S. Schaltin, L. Van Meervelt, J. Fransaer and K. Binnemans, Chempluschem, 2013, 78, 578-588.

S. Schaltin, N. R. Brooks, J. Sniekers, D. Depuydt, L. Van Meervelt, K. Binnemans and J. Fransaer, Phys. Chem. Chem. Phys., 2013, 15, 18934-43.

G. Vanhoutte, N. R. Brooks, S. Schaltin, B. Opperdoes, L. Van Meervelt, J.-P. Locquet, P. M. Vereecken, J. Fransaer and K. Binnemans, J. Phys. Chem. C, 2014, 118, 20152-20162.

37 S. Schaltin, N. R. Brooks, J. Sniekers, L. Van Meervelt, K. Binnemans and J. Fransaer, Chem. Commun., 2014, 50, 10248-10250. Lett., 2007, 10, D104-D107. 
and K. Binnemans, Dalt. Trans., 2017, 46, 12845-12855.

R. T. Carlin, P. C. Trulove and H. C. De Long, J. Electrochem. Soc., 1996, 143, 2747-2758.

Q. Chu, J. Liang and J. Hao, Electrochim. Acta, 2014, 115, 499-503.

P.-Y. Chen and I.-W. Sun, Electrochim. Acta, 2001, 46, 1169-1177.

Z. Liang and Y. C. Lu, J. Am. Chem. Soc., 2016, 138, 7574-7583.

Q. Chu, W. Wang, J. Liang, J. Hao and Z. Zhen, Mater. Chem. Phys., 2013, 142, 539-544.

Y. H. You, C. D. Gu, X. L. Wang and J. P. Tu, Surf. Coatings Technol., 2012, 206, 3632-3638.

Y. T. Hsieh, M. C. Lai, H. L. Huang and I. W. Sun, Electrochim. Acta, 2014, 117, 217-223.

M. Li, Z. Wang and R. G. Reddy, Electrochim. Acta, 2014, 123, 325-331.

Y. Katayama, R. Fukui and T. Miura, J. Electrochem. Soc., 2007, 154, D534.

R. Fukui, Y. Katayama and T. Miura, Electrochim. Acta, 2011, 56, 1190-1196.

C. Su, M. An, P. Yang, H. Gu and X. Guo, Appl. Surf. Sci., 2010, 256, 4888-4893.

M. Tułodziecki, J.-M. Tarascon, P. L. Taberna and C. Guéry, Electrochim. Acta, 2014, 134, 5566.

M. Tułodziecki, J.-M. Tarascon, P.-L. Taberna and C. Guéry, J. Electrochem. Soc., 2016, 163, D355-D365.

53 Y. Katayama, R. Fukui and T. Miura, Electrochemistry, 2013, 81, 532-534.

54 I. Rey, P. Johansson, J. Lindgren, J. C. Lassègues, J. Grondin and L. Servant, J. Phys. Chem. A, 1998, 102, 3249-3258.

J. B. Hodgson, G. C. Percy and D. A. Thornton, J. Mol. Struct., 1980, 66, 81-92.

A. Lagutschenkov, J. Langer, G. Berden, J. Oomens and O. Dopfer, Phys. Chem. Chem. Phys., 2011, 13, 15644.

G. M. Sheldrick, Acta Crystallogr. Sect. A Found. Crystallogr., 2008, 64, 112-122.

G. M. Sheldrick, Acta Crystallogr. Sect. C Struct. Chem., 2015, 71, 3-8.

59 O. V. Dolomanov, L. J. Bourhis, R. J. Gildea, J. a K. Howard, H. Puschmann and H. Puschmann, J. Appl. Crystallogr., 2009, 42, 339-341. 
K. V. Klementev, Nucl. Instruments Methods Phys. Res. Sect. A Accel. Spectrometers, Detect. Assoc. Equip., 2000, 448, 299-301.

M. Newville, J. Synchrotron Radiat., 2001, 8, 96-100.

P. Nockemann, M. Pellens, K. Van Hecke, L. Van Meervelt, J. Wouters, B. Thijs, E. Vanecht, T.

N. Parac-Vogt, H. Mehdi, S. Schaltin, J. Fransaer, S. Zahn, B. Kirchner and K. Binnemans, Chem. - A Eur. J., 2010, 16, 1849-1858.

63 N. Banić, M. Vraneš, B. Abramović, J. Csanádi and S. Gadžurić, Dalt. Trans., 2014, 43, 1551515525.

64 S. Osborne, S. Wellens, C. Ward, S. Felton, R. Bowman, K. Binnemans, M. Swadzba-Kwasny, N. Gunaratne and P. Nockemann, Dalt. Trans., 2015, 44, 11286-11289.

B. May, M. Hönle, B. Heller, F. Greco, R. Bhuin, H.-P. Steinrück and F. Maier, J. Phys. Chem. Lett., 2017, 8, 1137-1141.

66 X. Lan, T. Mochida, Y. Funasako, K. Takahashi, T. Sakurai and H. Ohta, Chem. - A Eur. J., 2017, 23, 823-831.

N. Aoyagi, K. Shimojo, N. R. Brooks, R. Nagaishi, H. Naganawa, K. Van Hecke, L. Van Meervelt, K. Binnemans and T. Kimura, Chem. Commun., 2011, 47, 4490.

D. Boys, C. Escobar and O. Wittke, Acta Crystallogr. Sect. A Found. Crystallogr., 1984, C40, 1359-1362.

B. B. Wayland, R. J. Fitzgerald and R. S. Drago, J. Am. Chem. Soc., 1966, 88, 4600-4604.

71 W. K. V. Gutman, R. Beran, Monat. Chemie, 1972, 103, 764-774.

72 A. B. H. Susan, S. Saha, S. Ahmed, F. Begum, M. M. Rahman and M. Y. A. Mollah, Mater. Res. Innov., 2012, 16, 345-349.

73 P. C. Howlett, E. I. Izgorodina, M. Forsyth and D. R. MacFarlane, Zeitschrift für Phys. Chemie, 2006, 220, 1483-1498.

74 N. DeVos, C. Maton and C. V. Stevens, ChemElectroChem, 2014, 1, 1258-1270.

75 Y. L. Xuaqi Xing, Dapeng Zhang, J. Power Sources, 2015, 279, 205-209. 